\title{
Quality Management and Its Role in Improving Service Quality in Public Sector
}

\author{
Abdulaziz Al-Ibrahim ${ }^{*}$ \\ Senior Officer in the Strategic Planning Department, Qatari Interior Ministry, Doha - Qatar \\ *Corresponding author: alibrahim1997@gmail.com
}

Received October 08, 2014; Revised November 28, 2014; Accepted December 18, 2014

\begin{abstract}
This article presents a detailed review of the literature relating to quality management and the various models that have been developed over the past decades for use in improving service quality. It begins by exploring the concept of service quality and introducing the Total Quality Management (TQM) approach. Thereafter, the article traces the historical development of TQM and considers how the practices associated with this philosophy have evolved over time to produce the fundamental model of Total Quality. Variables that are important in determining the success or otherwise of TQM approaches are then discussed, before the article moves to discuss how TQM has been extended from its original context within the private, manufacturing sector, into the public sector as a method to improve the delivery of services. Moving on from its consideration of TQM application in the public sector generally, the article addresses the use of TQM specifically in security organisations like the military, and the Six Sigma approach adopted by military organisations is presented. From this position, the use of TQM in police organisations is introduced before the article proceeds to consider a range of potential models of QM that may be appropriate in the context of law enforcement. In this respect, the usefulness of these different frameworks that are currently available for assuring quality is debated.
\end{abstract}

Keywords: total quality management, service quality, quality assurance, improvement, planning, process, model

Cite This Article: Abdulaziz Al-Ibrahim, "Quality Management and Its Role in Improving Service Quality in Public Sector.” Journal of Business and Management Sciences, vol. 2, no. 6 (2014): 123-147. doi: 10.12691/jbms2-6-1.

\section{Introduction}

The concept of Service Quality is essentially very simple, relating to the provision of goods or services that meet the expectations of those receiving them. Quality in the delivery of goods or services is now accepted as a critical aspect of business management in all fields since it is realised that only by satisfying its customers can an organisation hope to retain its customer base and indeed expand it for the future. It should be understood that it is not just in commercial contexts that the concept has meaning because in those institutions providing services to the public, the issue of delivering quality is equally important. Consequently, in discussing the concept of Service Quality and the various approaches to assuring this, the idea that it applies to both the private and public sector is included, although in discussing the origins of the concept it is very much on business where the focus lies (Douglas and Judge 2001).

Service Quality as an ideal developed around the world after a need was identified to establish and maintain service standards for organisations that wished to achieve and retain a substantial market share in their given fields. However, to some extent, the concept has always been present in the business and manufacturing sectors, although it was only in the $20^{\text {th }}$ century that quality standards began to be based upon scientific principles and accurate statistical measurements of quality. Standards seem to be the key feature in the concept of quality, it being suggested by Kehoe (1996), that consistency or excellence of standards in products or services is what is understood by the term 'quality'.

In fact, the current concept of Service Quality can be traced back to the early 1950s when the United States had a monopoly in fields such as agriculture, consumer electronics, and car manufacturing. At this time, and despite holding leading market shares in multiple fields, the US found its operations to be distinctly lacking in the area of quality, which was feared not only to have a negative effect on the potential to control various markets, but also to change the way that business functioned at the global level (Flexstudy, 2011). Kaynak (2003) argues that one of the main reasons why this became a problem was that there seemed to be no understanding of the fact that an organisation's quality management practices were closely tied to organisational performance. In other words, it did not seem to be appreciated that customers or clients were unwilling to pay for poor quality products that resulted from a lack of effective quality management (Sila, 2007).

The result was that the United States-dominated fields of car production and computer manufacturing suffered as poor quality management failed to meet up to customer expectations, and a rapid shrinkage of US market shares 
followed. For example, the US automotive industry saw a market decrease of about 8\% between the 1970s and $1980 \mathrm{~s}$, and the computer manufacturing sector experienced an even bigger decrease of $28 \%$ between 1979 and 1989 (Flexstudy, 2011). Watson and Gallagher (2005) suggest that early quality management models were effective in helping to manage environmental changes (e.g. economic variables social variables) that caused the quality of products to ebb and flow throughout the history of a given organization thus, serving to stabilize quality and enable greater stakeholder satisfaction with the organization.

Not surprisingly, in the attempts that followed to devise a quality approach to arrest and reverse these trends, several ideas were generated but it was the Total Quality Management (TQM) philosophy that quickly gained ground. In this conception, the belief was that quality could be achieved by considering all the service production process in its entirety, rather than simply focusing on individual parts of it. This fairly broad idea has given rise to different explanations of what TQM involves, depending upon the author's perspective and his/her focus within the subject area. Pfeffer and Sutton (2006), for example, argue that TQM practices emphasise evidence-based management that concentrates on creating visible and measurable improvements to processes, rather than on vague estimations of customer or client approval.

In the business world, TQM is seen as an addition to the traditional way of measuring quality (Kehoe, 1996), it being acknowledged as a technique guaranteed to evaluate a company's success in comparison with other similar business rivals. Dean and Bowen (1994) argued that all organisations, whether in the public or private sector, need to analyse their managerial effectiveness within their specific contexts and cultures in order to obtain information about their comparative performance with competitors, and hence take steps to become more productive. Within this context, the terms 'Total', 'Quality', and 'Management' can be taken to specifically mean: 'Total' as in made up of the whole; 'Quality' as pertaining to the degree of excellence, product or service; and 'Management' as an act, art, or manner of handling, controlling or directing (Besterfield et al., 2003).

Whilst there are various definitions of TQM (and this issue is dealt with in more detail in Section 5), Besterfield et al. (2003) offer a helpful and concise definition, suggesting that TQM is the integration of "fundamental management techniques, existing improvement efforts, and technical tools under a disciplined approach.”

In manufacturing, TQM is commonly used in areas such as supply chain management, since as noted by Kaynak and Hartley (2008), the focus in TQM is on internal and external activities within the business, and supply chain management is precisely involved with a range of such activities. Indeed, TQM is viewed as being particularly effective in manufacturing because the practices associated with it were developed quite specifically to meet the quality control needs of that sector (Crosby, 1985; Defeo et al., 2010; Ishikawa, 1985; Feigenbaum, 1951; Deming, 1986).

In an article published in Business Week in 1989, there was a comment on this quality development to the effect that the Japanese market was creating 'remarkably high standards' in terms of production and that within the production markets generally, there were continual losses being suffered by other nations' companies. This compelled the writer of the article to suggest that companies must 'get better or get beat', and knowingly or otherwise, it was this phrase that became a driving force for businesses (both in and out of production) to develop higher standards which would ultimately equal 'value for money' as well as providing a long-term customer base (which essentially equals a sustainable business). This increased focus on TQM helped businesses to improve their efficiency and their effectiveness as well as to create tools to better manage the quality of products and services for their long-term customers. One major suggestion as to why TQM practices have been so successful in increasing organisational performance is that TQM serves as a link between an organisation's business or corporate strategy and its performance. In other words, it creates a system of checks and balances to ensure that an organisation's business strategy is successful (Prajogo and Sohal, 2006).

Having observed the applicability of Service Quality Management philosophies and techniques to the manufacturing and service sector, it is also appropriate to note that the new focus on providing quality of service gradually spread to areas outside of these sectors. For instance, in the United Kingdom, service quality standards are now frequently used in the delivery of social services as a means of controlling quality of care for different types of clients, such as care for the elderly (Flexstudy, 2011). In such situations, local authorities sub-contract various care services to the Voluntary Sector (non-profit organisations with no government affiliation, generally known as charities). These organisations are invited to tender for business, and in so doing, they provide a document detailing how they intend to achieve the specifications as described in the contract. Once an organisation has won a tender, it then begins a continual self-monitoring exercise using a Quality Assessment Framework, which acts as a tool to measure itself against the targets established in the contract and allows it to monitor when the key milestones have been (or are being) achieved. This also feeds into the 'Value for Money' exercise in which the organisation is required to produce evidence that it is providing positive outcomes (relevant to contract stipulations) in order to justify the expenditure being allocated to it. All such organisations have a vested interest in providing quality services as a means of retaining their customers (Local Authorities) for future business, and to ensure their own reputations as organisations that can deliver the requirements of their contracts (Flexstudy, 2011).

Furthermore, the idea of service quality is seen in many other service areas such as retail, hospitality, and healthcare. These sectors not only have the similar goals of securing business but they also have the aim of developing a reputation for quality and excellence of service (Flexstudy, 2011). Indeed, it can be seen that quality management is as critical, if not more so, in the service sector as it is in manufacturing, since customers have the expectation of high quality service that is not necessarily present in regard to manufactured products (based upon cost).

As a quality framework, TQM has been used with variable success within the public sector, included in which is the military with its aims of providing external 
security for citizens. However, there are many arguments surrounding its use in the public sector generally. One view in support of the applicability of TQM to the public sector is that government is itself, a service-driven industry and hence, would respond well to its philosophy, whereas one argument against the use of TQM in this arena is that government has different goals from business and consequently, the approach is inappropriate (Kluse, 2009).

In the specific case of military organisations, while some nations have successfully adapted TQM for use in this respect, nations with larger and more modern militaries have chosen in many cases, not to do so. The primary reasoning behind this is that the goals and aims of the military are at odds with some of the core philosophies of TQM. A secondary reason given for the lack of TQM in modern militaries is that military organisations (one such example being the United States Air Force) often have their own Quality Assurance (QA) programmes that have been in place for several decades (Rinehart, 2006).

As an extension of the military, policing with its aim of providing internal security for citizens is another service group where the concept of TQM is applied. The aim of securing business is clearly not applicable in this scenario, but it is nonetheless essential that a police force gain a reputation of excellence and quality in order for all the stakeholders (citizens, local authorities, governments) to have continued confidence in the service that is being provided.

In nature, TQM may not offer very much which is different from previous methods of quality control, and indeed this is one argument proposed against it (Oakland, 2003; Rawlins, 2008). Other criticisms are that TQM does not adapt well to new business sectors, the public sector generally, and to those service sector environments that rely primarily on the internet as a means of conducting business. However, Defeo and Juran (2010) claim that the applications of TQM to a variety of situations and organisations are just as effective today as they were in the 1960s and 1970s. This particular debate is centred on the comparison between the TQM process model and other process models of QM such as ISO 9000, SERVQUAL, and EFQM.

Yet another complaint about TQM is that it is often seen as conflicting with other management activities or forms of quality control. Lopez-Mielgo et al. (2009) state that some find the process of quality control restricts a company's ability to be innovative. However, their research revealed that this relationship is bi-directional meaning that when properly used, TQM fosters innovation and creativity rather than negating it.

And certainly, as a QM practice, TQM is still adopted by many firms due to the fact that the organisations that do use it have shown marked increases in performance in those particular areas where the philosophy is applied (Corredor and Goni, 2011). These performance gains are also seen when models related to TQM processes such as ISO 9000, SERVQUAL and EFQM are utilised by firms. In reality, research indicates that TQM is not harmful to innovation within organisations and that its use demonstrates no negative impact on corporate or organisational innovation (Perdomo-Ortiz et al., 2006).

\section{Historical Development of the Total Quality Management (TQM) Philosophy}

Some scholars who are interested in the quality of products have traced the origins of TQM to thousands of years ago. Dennis (1997), for example, has explored the quality issue by going back to 1700 BC when King Hammurabi ruled the Babylonian Kingdom and made a very strong ruling on product quality and liability in the construction sector by stating;

"If a builder constructed a building then it falls into pieces and the owner is killed then the builder shall also receive the death penalty. If the children of the owner are killed then the builders' children shall also die."

Comparatively more recently, however, at the end of the $13^{\text {th }}$ century, artisans started to form guilds in order to develop product quality and organise themselves formally (Juran, 1995). During this period, the products of these artisans were frequently inspected and high quality goods were marked with special symbols (Wolek, 1999), a method that was used continually until the Industrial Revolution at the beginning of the $19^{\text {th }}$ century. Other inspection techniques that originated in the medieval guilds have remained, however, and are still in use today, forming many of the current concepts of TQM. Variance minimisation, for example, is one such idea that developed at around this time in order to ensure that the products created by different members of the guilds were consistent in quality and appearance. And while the fact that manufactured goods were produced by individual craftsmen on a single item basis and therefore, limited the ability of the guilds to develop a systematic QM approach, the presence of the basic principles of TQM were perceived as being present at this time (Wolek, 1999). Clearly, research on the medieval guilds indicates that TQM has a strong basis in historical business and professional practices, and that it developed out of a need to control the quality of goods at a time in history where most goods were hand-made rather than being massproduced. These concepts developed over time as manufacturing became more systematic and standardised, eventually leading to the sub-field of business known as Quality Management.

Yet another perspective places the beginnings of TQM in the late $19^{\text {th }}$ century with a management theorist named Frederick Taylor. At the time, Taylor argued that frequent inspections of manufacturing facilities were critical in the effective and efficient management of factory shop floors (Sliwa and Wilcox, 2008). Taylor focused on the idea that inspections helped workers and managers to concentrate upon producing high quality goods rather than on producing goods quickly. Another aspect of Taylor's focus on inspections as a means of quality control was that the inspections would observe the manufacturing process as well as the functioning of equipment and thus, be able to identify problems that might lead to defective product quality.

TQM theory further developed in the 1920s and 1930s when WA Shewheart developed a scientific process for QM that was responsible for setting industry standards well into the 1950s. Shewheart's 'Control Chart Theory' embodied several key QM processes such as control limits, and assignable and chance causes of variation. 
In their efforts, both Taylor and Shewheart can be considered as the Founding Fathers of TQM (Sliwa and Wilcox, 2008)

The decisive moment for TQM occurred just before World War II, when the extraordinary expansion of manufacturing productivity associated with that war inevitably led to the concept of quality focus on product and performance. It is suggested that interest in TQM increased somewhat during the Second World War as the result of the need to concentrate on improving production of goods to power the military that needed not only weapons and ammunitions for their soldiers, but also supplies such as uniforms, food, and pharmacological items (BPIR, 2011).

This in turn led to the eventual emergence of TQM in its present and recognisable form after the war when the Japanese became preoccupied with quality improvement as the result of the need to rebuild their manufacturing sector (Fisher and Nair, 2009). Deming is considered to be the main agent in helping the Japanese reorganise their business and management systems during the post-war period in the effort to stabilise the Japanese economy (Saylor, 1992). His book Out of the Crisis demonstrates his theory of chain reaction in business management and the relationship between quality and improved productivity (Wayhan et al., 2010). It should also be said that Deming adapted Shewheart's statistical quality control ideas through a series of lectures to Japanese engineers and CEOs that he gave to the largest Japanese organisations (Deming, 1986).

Deming's (1986) observations of Japanese, American, and European management styles led him to reconsider QM in respect of the Japanese business environment, since several differences emerged between this and the Western countries. One particular instance was seen at Toyota Inc., where it was obvious that the focus was on group, rather than individual performance. In this case, the emphasis was on loyalty and dedication to the group rather than to personal promotion. And the outcome was that Japanese managers were reluctant to change, and hence there were quality issues. The Western approach, however, was more individualistic and American and European managers were seen as more inclined to promote workers according to their merit, rather than their dedication to a team, or on their seniority. The focus on the individual is seen in Western workers' preparedness to leave a company which they do not feel is rewarding them for effort, whereas Japanese workers with their preference for collectivism, are predisposed to remain loyal to their employers, even when they are dissatisfied with their rewards.

Atkinson (1990) characterises the changes that occurred in terms of QM in manufacturing between 1951 and 1989 as a complete change in how the concept of quality was viewed within organisational cultures. Ishikawa (1985) argues that many of the principles on which TQM is based incorporate a particularly Asian worldview in terms of the group rather than an individual focus, and in terms of how organisations are viewed as holistic units rather than as several sections or sectors with differing goals and purposes. The TQM perspective adopted by the Japanese in the 1950s was actually used to great effect by organisations such as Toyota that adopted TQM to solidly cement its position as one of the top automotive manufacturers in the world (Kakuro, 2004).

Another important contributor to the development of QM in Japan was Feigenbaum, who introduced the 'costof-quality' idea in his book entitled Total Quality Control. The importance of this was that TQM acquired a focus on cost reduction (Hanna, 1995). In Japan, Ishikawa presented a theory of seven basic tools of quality, which could be used to solve any quality-related problems in an organisation. Other Japanese experts have also stressed the importance of a proper design strategy with exact specifications that focused on best target value(Saylor, 1992).

It is suggested that there is a significant difference between 'control of quality' as is practised by the Japanese, and TQM as is practised by the American and European business sectors. In Japan, QM has as its main concern, the control of quality within the company in every aspect ranging from employees to the environment, to products and services, whereas in the American and European business sector, quality is often solely focused upon products and services (BPIR, 2011; Powell 1995).

Others with an interest in quality in the service sector consider the history of TQM development by referring to the United States Department of Defence and its adoption of TQM principles for use in the military (Ahmad and Kimberly, 1992). In this respect, the idea of TQM was formally introduced in 1988 to improve the overall efficiency of military defence in the US within approved financial limits. Later during that same year, TQM became an issue of prime importance when the Undersecretary of Defence approved its use for government projects.

Other federal agencies within the US began adopting TQM practices during the mid-1980s, leading to the formal introduction of TQM practices in 1988. This is generally recognised as an accepted way to introduce TQM principles as a part of any organisation that is considering improving its efficiency for reasons of competition from other sources, improved customer satisfaction, or just to be economically viable (Hyde, 1993). Essentially, it was different departments within the organisation testing methods to manage quality, and observing the results, and if the method proved successful, then the process could be delivered to other departments. When using this method of deployment the organisations in question quickly discovered which areas of their operation were in critical need of overhaul. And finally, when TQM was shown to be successfully applied to these areas, it then became central to the smooth running of the entire organisation (Saylor, 1992).

\section{Development of TQM Practices}

\subsection{The TQM Model}

In order to understand the significance of TQM it is necessary to examine the history of business practice. The way in which businesses were organised changed after the Industrial Revolution, and this change indirectly brought about the emergence of TQM. In the first instance, the focus was on the quality of the product delivered by manufacturing, but more recently this has changed to the quality of the service provided, since it has been appreciated 
that the tremendous success of various Japanese companies, driven by quality-oriented approaches (including an emphasis on service), jolted the American economy into redesigning its management practices (Saylor, 1992). One reason why TQM seems to have developed so effectively in Asian nations such as Japan is that TQM practices and procedures lend themselves to Asian cultural norms and values in that they focus on the effectiveness of the group over that of the individual (Kull and Wacker, 2010; Mehra, \& Ranganathan 2008).

In the modern industrial world, the concentration has further developed to include customer and/or client services. This has become even more critical in the United States and Europe since in many cases the economy has shifted from an industrial/manufacturing-based economy to one, which is service-based and consequently needs to satisfy the expectations of clients/customers in respect of the services they receive rather than the quality of goods they purchase.

Clearly, it is important to appreciate why TQM is important in the manufacturing and service sectors, and research suggests several reasons for this. One is the need to ensure that goods or services are meeting the needs of companies' stakeholders (e.g. customers/clients, shareholders, employees, management, local authorities). Once this need is met, stakeholder perceptions of an organisation's credibility are increased. Another reason is the need is to promote acceptance of the idea that the provision of high quality goods is the ethical thing to do in terms of business, since in itself, this is cost-effective and profitable for a company. Furthermore, the organisation can profit from the positive impact of the knowledge that it is providing high quality goods and services (Rabinowitz and Vilela, 2012; Aguilar-Save'n, 2004).

TQM responds to these requirements by presenting the means whereby managers can monitor and control risks. It offers methods that allow any issues concerned with the quality of service or products to be efficiently and effectively addressed by those responsible, and consequently, it guarantees the highest quality of those services or products.

Ghylin et al. (2008) have defined four major concepts or dimensions of TQM. The first of these conceptions is that of general quality which Ghylin et al. (2008) argues is a multi-dimensional concept that applies to several different aspects of business. The second dimension of quality is product quality, which refers to the quality of manufactured goods or objects. The third concept is quality of service, which implies that when an organisation provides a service there should be a standard or set level of quality for that service. The final dimension is quality of life, which is applicable to the previous three dimensions and claims that the quality of goods and services influences or affects the customer/client's life positively or negatively.

Hence, it can be seen that TQM is more than just a phrase or ideology; it is a procedure in its own right, which based upon the origins, has been refined to the point where it can now be broken down into five basic cyclical elements (Edwardsoft, 2011). These five fundamentals are: Customer Focus, Planning Process, Process Management, and Process Improvement, and upon reaching this last element the process repeats, beginning with Customer Focus. Figure 1 depicts the entire cycle.

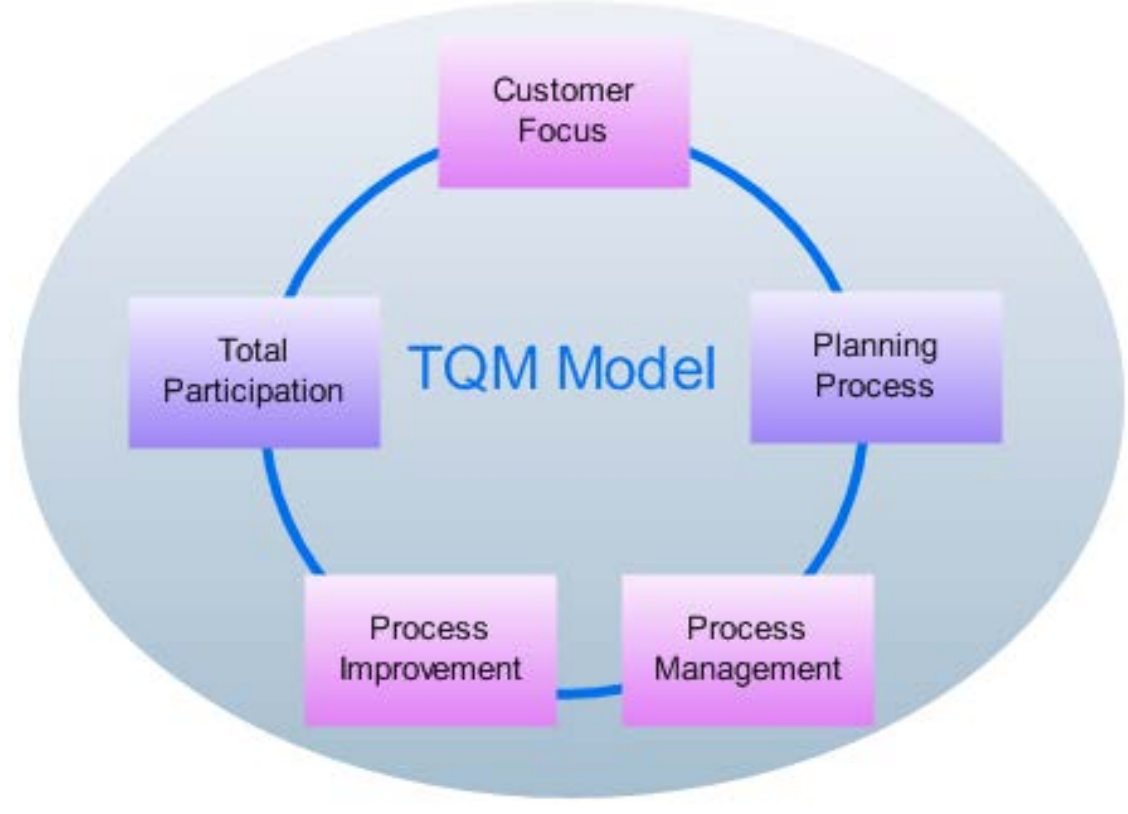

Figure 1. The TQM Process

Customer Focus involves researching what customers or end users want from products or services. This information is collected in a variety of ways including focus groups, customer interviews, and/or detailed user specifications. Undoubtedly, this knowledge is invaluable when it comes to planning how to shape the service or product in order to meet the demands (and expectations) of its potential customers. There is an emphasis in this element on the belief that the customers are the central focus of the organisation as these are the individuals who will purchase the manufactured goods or services being offered by that organisation (Edwardsoft, 2011), and hence, their expectations must be met. Prajogo and Cooper (2010) argue that quality customer service is one of the most important aspects of TQM because in any customeroriented business the customers are the organisation's main stakeholders. 
This leads into the Planning Process where the framework of the project is laid out using information that has been gathered from the full range of potential customers. Effectively, this can be considered the design phase since any possible barriers that may prevent it from meeting the specifications are identified, and the organisation is encouraged to explore different methods of dissolving any such obstacles. This is also that element of the cycle, which considers production methods in terms of the available resources, materials needed, and the location of production (Edwardsoft, 2011; Ghobadian and Gallear, 2001).

Process Management is concerned with ensuring that the production of goods and the implementation of services operate efficiently, and that any problems that arise are corrected at their inception. Essentially, it is the part of the cycle, which acts as an oversight in converting the planning into practice. During this phase, the aim of the organisation is to produce the goods or to implement planned or specified services (Edwardsoft, 2011). The quality aspect of Process Management mainly involves providing the goods or services that were specified in the planning element of the TQM cycle.

The Process Improvement part of the cycle is concerned with 'troubleshooting' and focuses on issues such as: events that occurred (both resolved and unresolved) during the process management element of the TQM cycle, feedback from customers that could not be included in the production process, and feedback that has come after production has been completed. Process Improvement explores how these issues can be resolved to increase quality and productivity in the future rather than purely attempting to deal with a problem on a temporary basis, so that the mode of production does not grind to a halt.

Total Participation refers to the involvement of the entire workforce to guarantee quality of an organisation's production/services. It also embodies the external customer as a vital feedback mechanism to confirm that the product/service meets expectations. In turn, internal customers manage such feedback by implementing strategies to control for risks and establish standards for quality maintenance. In respect of policing, a main problem is the hierarchical nature of law enforcement agencies, which can militate against the free flow of information from the external customer to the internal customer, or indeed information pertaining to what is happening purely within the organisation. Furthermore, the departmental or precinct level, having encountered a quality issue, may deal with this on a piecemeal basis rather than reporting the matter to the top management for the development of an overall strategy to combat the issue.

After this element, the entire process is repeated, beginning with the Customer Focus element, which is accepted as one of the most critical in the TQM process. When customers see that their views are incorporated into the end product or service, their inclination to provide valuable input if asked to participate in customer-focused research at a later date (as for example when a company releases a second generation item), is enhanced, and consequently the knowledge of the customer is increased as the customer focus becomes continually more refined. This leads to sustained sales, as the organisation is able to provide frequent customers with the chance to be involved in the Service Quality Management process (Edwardsoft, 2011).

The TQM process relies on those operating within the different elements (including customers) to provide the best that they possibly can within these elements in order for the process to work effectively. This does not mean that if all elements were functioning perfectly, there would be no problems, but rather that in the event of anything going wrong, there is a 'fail safe' to minimise the fall-out, and that the issue in question is given due consideration to ensure that it can be resolved and does not recur.

It has already been noted that one of the important dimensions of TQM is the provision of quality service to customers (Prajogo and Cooper, 2010), and this implies that the process of increasing and improving customer focus is given due weight in the TQM cycle. Hence, the notion of Total Participation would seem to be critical to the approach, and could be considered the second most important of these elements as the process begins with Customer Focus and ends with Total Participation.

\subsection{The Deming Cycle}

A second process identified in the literature is the Deming Cycle. Much like TQM, this is relatively simple in terms of what it involves. It is also remarkably similar to the previous process in terms of the elements it utilises. The first element involves planning. During this stage the organisation focuses on assessing the needs of its customer/client base (Customer Focus), setting goals, objectives and outcomes, setting benchmarks that will let the organisation know when it has reached a goal, and risk management (BPIR, 2011).

The second element is what Deming terms the 'Do' process. During this phase, goods are produced and services are implemented. The main goal of this part of the process is to involve the stakeholders in the production or implementation process. Secondary goals involve taking care of production and implementation logistics, and doing research to determine whether or not the product or service will be successful. This involves elements of Customer Focus, the Planning Process, Process Management, and Process Implementation (BPIR, 2011). Here, it is necessary to appreciate the significance of the internal and external customers. Deming (1986) includes within his concept of internal customer, employees, managers, and company owners, whereas his image of external customers includes, customers/clients, stockholders, and vendors. Until the development of the EFQM, TQM models have mainly concentrated on quality improvement as perceived by external customers, and have ignored the fact that internal customers should themselves be satisfied before they can provide products and services which attract such approval from external customers. In this respect, opportunities to become proficient in their jobs, and the provision of adequate resources and equipment, are essential components in a quality initiative.

Deming's third element is concerned with 'Checking' the quality of goods or services. This means using various methods of assessment such as observation or quality checklists to ensure that goods and services meet the specified goals and objectives (BPIR, 2011). 
The fourth element of Deming's cycle is referred to as 'Acting', and during this phase, the organisation focuses on selling or marketing a product to the public. This is where the organisation begins to gain an understanding of whether or not a product or service is going to be profitable (BPIR, 2011).

The final step of Deming's cycle involves analysing the process to determine whether there is anything about a product or service that can be changed or improved in future implementations (BPIR, 2011). Much like the Process Improvement element discussed by Edwardsoft (2011), this process involves the customer/client in helping to determine what aspects of a product, or service could be improved in the future. Deming's cycle is depicted in Figure 2

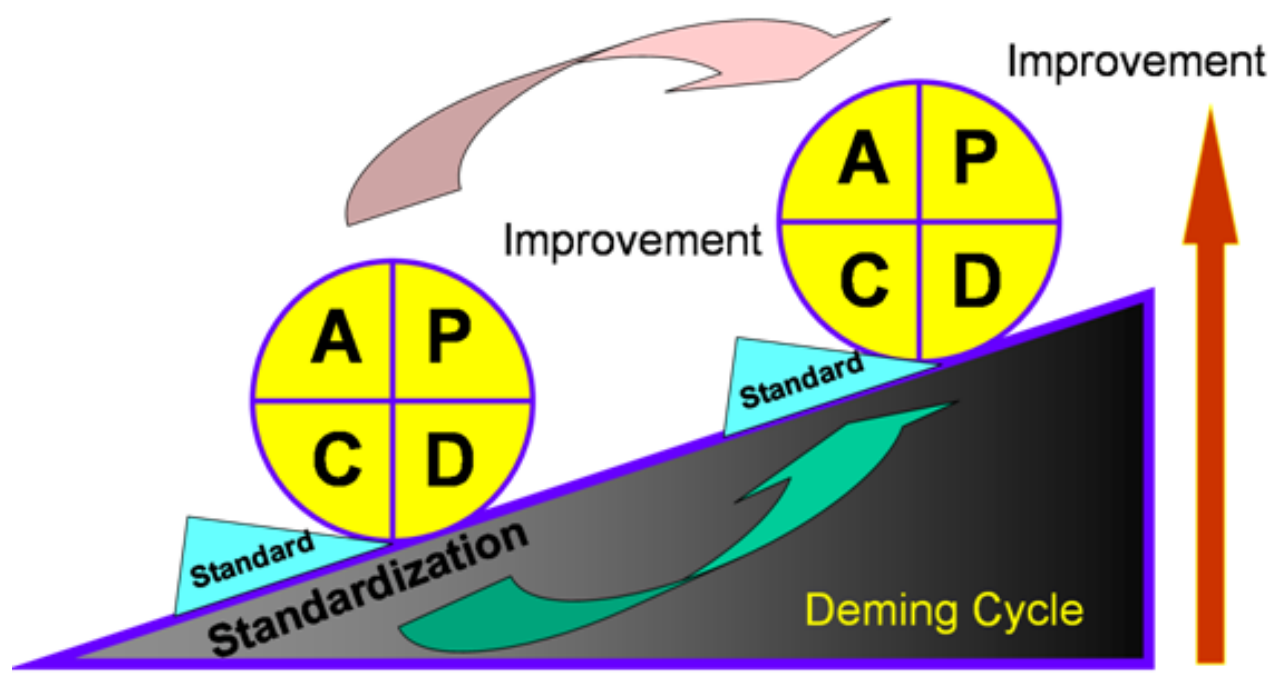

Time

Figure 2. Deming's Cycle

Significant variation can be found between the TQM Cycle (Figure 1) and Deming's Cycle (Figure 2). In the Deming Cycle, the emphasis on creating a balance between 'doing', 'checking' and 'acting' in an attempt to achieve standardisation through quality improvement processes. Should the balance change, and any of the elements fall below their required level (and hence roll down the wedge-shaped base), quality will decrease, whilst if those elements are seen to move gradually up the base, quality is seen to improve over time. The TQM Cycle shown in Figure 1 is less complex in that it does not focus on the continuous and incremental improvement with time but simply repeats a process until problems are solved.

\subsection{Potential Obstacles to Successful Implementation of TQM}

As mentioned already, TQM is not simply an ideology, but a sophisticated ongoing process demanding the absolute commitment of everyone in an organisation (Edwardsoft, 2011; Joiner 2007). Consequently, it can be understood that the success of a TQM initiative is dependent upon several variables, and these represent potential obstacles to the effectiveness of implementation.

On this issue, Jayaram et al. (2010) suggest that issues such as the size of the organisation, how long the organisation plans to implement TQM practices, and whether an organisation is unionised, all have a powerful influence on whether an organisation can implement TQM practices successfully. Eskildsen and Dahlgaard (2000) raise the issue of employee contribution and loyalty to the organisation, arguing that this represents another variable in the equation because in the absence of these positive emotional and physical inputs from employees, the fundamental objectives of any quality initiative are not likely to be met.

In respect of objectives, Fernandez and Ratney (2006) highlight that there must be a genuine need for the TQM initiative being introduced, and this ties in with the comments by Eskildsen and Dahlgaard (2000) that client satisfaction is necessary to achieve TQM goals. This means that organisations must know what their customers want and translate that into the genuine need mentioned by Fernandez and Ratney (2006).

Fernandez and Ratney (2006) also consider the ability of the organisation to plan properly as an important variable, and echo the comments made earlier in respect of the need for support from employees (internal customers) (see Eskildsen and Dahlgaard, 2000). They also introduce the potential obstacle of lack of support from management, which may or may not result from lack of real understanding among management of the TQM philosophy. On this issue, Koehler and Pankowski (1996) noted that in US government departments, failures in the implementation of the TQM philosophy were traced to a lack of understanding by government administrators of the TQM processes, meaning that TQM principles were perceived subjectively in different departments, thereby preventing any real standard-setting operation.

Whether the organisation has the support of all its stakeholders stands as another variable in the search for successful implementation, as also does the extent of the material resources an organisation enjoys (Fernandez and Ratney, 2006), for example, technological resources are imperative to facilitate the communication network demanded of effective TQM initiatives. 
The point is made by Jayaram et al. (2010) that these variables may determine the decision to implement TQM in the first place, the alternative possibly being to adopt one of the other models of QM. Such ideas are also expressed by Tari et al. (2007) who suggest that these variables determine the type of quality management system selected by an organisation. What is certain, is that it is necessary for organisations to take these variables into account when seeking to introduce TQM or any other TQM model (Jayaram et al., 2010; Tari et al., 2007; MacAdam Henderson and Hazlett 2008), and hoping for success in its implementation.

Such variables are important in that their impact may be negative or positive depending upon the situation. Unlike critical factors which arise suddenly and require some immediate action to manage them, variables have permanent influence but influence which may change. For example, an organisation's external customers may have negative views of a particular product and thus represent an obstacle to overcome, but may be valuable when testing out a new product or service. Hence, they may form a barrier in one particular TQM context, but an advantage in a different one. Consequently, they have to be acknowledged as playing a part in determining quality although it is not possible to identify that part in the absence of a particular context.

\section{TQM: From the Manufacturing to the Service Sector}

In the decades between 1950 and 1970, American dominance in the business world was such that quality was not perceived as an issue. However, in the late 1970s, America began to face competition from other countries such as Japan that placed a higher value on quality management than the US did. Consequently, the US started to explore the TQM philosophy with greater motivation, and eventually adopted a more integrated approach that changed QM methods within American business organisations. This dynamic brought forward a new wave of TQM theorists with their own approaches to TQM issues. Most notably among them was Philip B Crosby. In his book entitled Quality is Free, Crosby pointed to shortcomings in the American industrial process that, at the time, were acceptable to the majority of American companies and the US government (Bauer et al., 2006).

Kakuro (2004) argues that one of the main reasons why TQM practices have enjoyed so much success in Japan is that Deming, Crosby, Feigenbaum, Juran and Ishikawa, all created models of quality control processes that approach the issue from a scientific perspective. Ultimately, this was applied to other organisational sectors including the service sector, knowledge sector, and public sector, which have all been successful to some extent in achieving improvements through the use of TQM practices in recent years. A second reason is offered by Moura-E-Sa and Abrunhosa (2007) who suggest that it is TQM's successful application in manufacturing that has encouraged managers in other sectors to experiment with the philosophy; and another reason is offered by Hung-Min (2007) who argues that TQM helps to create an organisational environment that increases both performance and innovation and that is not bound by the nature of the activity undertaken by the organisation.

In the 1980s, Peters and Waterman gave the American business world a new TQM model to focus on when they examined the practices of the top American companies and, in particular, why they were so competitively successful. In their book entitled In Search of Excellence, they distinguished eight key factors that explained in some detail, the interactive relationships between management and staff that contributed to the overall high level of performance in these companies. This was accredited to the complete dedication of all involved in the quality process within the organisations concerned (Peters and Waterman, 2004).

Building on this work, in 1987 Peters explored the idea of constant change within the business environment, publishing his book Thriving on Chaos as a means of disseminating his beliefs in this respect. Peters (1987) argued that companies should not become complacent as 'excellence' was an 'ideal' that could never be achieved, and hence, management must constantly adapt to the ongoing innovation within the daily economic environment. Hough (2004) observes that one result of the efforts of Peters and Waterman (2004) was a change in how people perceived TQM practices in the service and knowledge industries in comparison to the way they viewed it in manufacturing and business.

This led in turn to other American theorists (Harrington, Shores) revising their ideas to meet the contemporary challenges of implementing TQM in American industry. Sila (2003) argues that one of the reasons that TQM is seen as remaining valuable in the modern organisational environment is that it is supported by existing organisational theories, and still demonstrates a marked improvement in the relationship between performance and implementation of TQM practices, despite claims that the theory underpinning TQM is outdated.

This revision of existing theory in TQM prompted the American Department of Defence to adopt the TQM approach in 1988 with an emphasis on continuous quality improvement. This marked the beginning of an interest in TQM by the public sector generally, and today the philosophy has been adopted by many other government agencies and other private and public sector organisations.

Existing literature offers several different definitions for TQM as mentioned already in Section 3.2. Each author has his/her own interpretation according to his/her preferred interests in TQM practices/applications. However, debates on TQM cannot be resolved without presenting and recognising the role of the five TQM leaders, these being:Deming, Juran, Feigenbaum, Crosby, and Ishikawa. Whilst each of these theorists has contributed something distinct to the concept, as found by Reed et al. (2000), it is possible to link the theories and practices of these TQM experts, and it is clear that as noted by Hoang et al. (2010) there are similarities in terms of the elements of TQM. They all agree, for example, on the importance of the six factors: customer satisfaction, cost reduction, leadership and top management commitment, training and education, team work, and organisational culture, and they all accord equal importance to each factor. Clearly, therefore, this agreement testifies to the continuity in respect of all these theories and models as they have evolved over the last half 
century. Nonetheless, despite their shared ideas, the original five major contributors do have different priorities in terms of TQM research and practice.

The emphasis in early TQM philosophy, with the exception of 'customer satisfaction', is strongly slanted towards managerial control and overview. Frederick Taylor and other pioneer theorists in the management field did not believe that managers could control customer satisfaction. Subsequently, however, theorists challenged this assumption believing customer satisfaction to be within management control. This led to an increased focus on the role of customers/clients in TQM and greater attention to barriers in the TQM process that might cause an organisation to lose customers/clients (Charintimath, 2003). The fundamental premise of TQM theories is that if customer needs and wants are kept in focus, customer satisfaction can be controlled.

Authors who concentrate on customer satisfaction define TQM as a plan that addresses the management processes within an organisation and understands the needs of internal and external customers, using these needs as the basis of the design for a complete system for improvement (Longest et al., 2000). If the internal customers (the organisation's employees) believe in the quality of the product or service they are producing or selling, then this confidence will transfer to the external customer. According to Mohr-Jackson (1998), TQM is an approach, which aims to make a change in an organisation's culture, and this is achieved by generating satisfaction among internal, as well as external customers. Clearly, external customer satisfaction is important in order to achieve TQM goals (Eskildsen and Dahlgaard, 2000), but without employees' contributions and loyalty to the organisation, such quality goals are unlikely to be met, and overall quality aims are highly likely to fail. This approach to the process places emphasis on external customer approval for the product/service, recognising that such external approval may only be achieved by transforming the motivation of the workforce to achieve these TQM objectives.

Workforce motivation is in part, an outcome of organisational culture, and this in itself is a product of nationality which has a significant effect on behaviour within organisations as mentioned earlier when considering the differences in approach of Japanese workers to that of American and European workers. For instance, national characteristics determine promotion criteria, and whether merit (performance), seniority, loyalty or dedication function as the benchmark for reward. National culture also impacts upon the perceptions of whether a business is successful or not. In this respect, Corporate Social Responsibility (CSR), which embodies the idea of conducting business ethically, has become a yardstick by which companies in Western countries evaluate their success, and consequently the TQM processes reflect the need to meet that objective. Corporate Social Responsibility recognises a company's obligations to all its stakeholders, going beyond its immediate customers.

One major argument is that the use of customer-focused TQM provides a competitive advantage for companies that choose to use TQM quality control processes over other methods of quality control. Dakic (2010) argues that the extremely competitive market in some manufacturing and service sectors has encouraged the development of more aggressive TQM practices that have a greater focus on allowing an organisation to compete in a market where customers/clients may be faced with dozens of similar products or services and must make a determination of which product or service to purchase.

Another author who is also interested in TQM policy, Atkinson (1990:9), defined TQM as "a strategic approach to producing the best product and service possible through constant innovation.” Holjevac (2008) equates 'best ... possible' with 'enrichment', defining TQM as a system of developing and enriching the efficiency of an organisation's performance. Holjevac (2008) argues that all the employees in the organisation have a role to play in the QM approach starting from the most junior levels right up to the general manager. It was from this interaction that took place between Atkinson (1990) and Holjevac (2008) that different theories of continual development and the modern image of dynamic management emerged. This closely resembles the approach used in Japanese organisations where the focus is on 'Total Quality Control' at every level of the organisation.

The Deming Prize Committee (1986:5) states that TQM is "a system of activities to ensure products and services of the quality required by the customers are produced and delivered economically.” This strikes a realistic note as in a competitive world, cost of production and price to the customer, must be a priority. This is also true in the service industry where a customer or client is not necessarily purchasing tangible goods, but rather services that the organisation provides. For example, the military provides the service of national defence to its clients (the people and government of a given nation), and law enforcement protects the people living within the boundaries of a local authority (town, city, region, and province) from criminal activity.

Feigenbaum's (1988) definition of TQM is a most comprehensive one. He states that "a total quality system is defined as one which embraces the whole cycle of customer satisfaction from the interpretation of his requirements prior to the ordering stage, through to the supply of a product or service at an economical price and on to his perception of the product after he has used it over an appropriate period of time” (Feigenbaum, 1988:15). This definition covers virtually every aspect of the TQM cycle including, customer focus, process planning, process management, and process improvement, which effectively provides a definition of the TQM, cycle as well as TQM generally. To Zbaracki (1998) the concept of TQM provides a simple and essential description of quality management that allows middle and upper level managers to oversee product and service quality in direct and uncomplicated manner.

As a concept, 'Quality' implies that an organisation understands what customers require of a product or service, and is able not only to meet this requirement but can also exceed the expectations of the customer. This demands a particular culture that can in fact, be seen to be embedded in TQM philosophy, which embraces the idea of encouraging an organisation to strive for continuous improvement in its values and methods of operation in order to achieve customer satisfaction. Organisational culture is often a reflection of national culture, and consequently it differs from country to country, but it can 
also be a product of ways of working in different industry sectors (Prajogo and Brown 2004). Nonetheless, the idea of a shared value system is common, and strategies aimed at instilling a learning culture within an organisation can be effective in producing better performance, cost reduction, greater profit, and an increased international market share (Kanji, 2002). TQM philosophy aims to do the right thing from the outset in order to save time and money that in turn leads to customer satisfaction.

In fact, TQM philosophy not only has an impact upon the way individuals act within their organisation, but it also filters through to their personal lives since whilst originally, the idea was conceived for implementation in all business organisations, whether they operated in the public or private domain, the basic tenets of TQM can be viewed as a philosophy for life. Therefore, it is not limited to any specific business organisational structure, and this is a strong justification for theorists feeling comfortable in their application of TQM to private, public, and non-profit organisations (Agus, 2004).

TQM represents an entire philosophy regarding constant development - lifelong learning. It emphasises the importance of involving stakeholders in the quality process, and as noted by Choi and Enoch (1998), it stresses the importance of providing complete satisfaction to both internal and external customers. In matters of cost reduction, TQM seeks the best methods, and it uses measurement tools and other techniques to achieve high quality standards (Kannan and Tan, 2005). Detecting defects in the products, dissatisfaction with the service and focusing on doing the right thing from the start are core beliefs in the TQM philosophy. At the same time, reducing losses and eliminating variability are also significant objectives. Furthermore, TQM supports the development of interactions between employees, suppliers, and customers. As a final assumption, TQM takes for granted the fact that there is determination within the organisation to achieve a high standard of quality.

In any analysis of the TQM philosophy, it is essential to consider the theorists who were responsible for developing TQM principles. In this respect, Edward Deming is well known for his 14 Points of Quality Management presented to Japanese industrial leaders in the 1950s as part of an exchange of ideas surrounding QM between Japan and the US. These ideas have been modified over the last 30 years and are as follows (Anderson et al., 1994):

Determine and announce the objectives and purposes of the organisation: Management should continuously explain the reasons behind their thinking. They should communicate with employees, customers, investors, suppliers and society regularly, and constantly refer to their quality management philosophy.

Adopt and learn the new philosophy: Everyone from the junior positions in the organisation to the most senior of managers must understand the new philosophy and receive the required training to implement it.

Limit dependency on inspection: Statistical techniques rather than mass inspections should be used. The aim of inspection is to reduce cost, and mass inspections are costly.

The price factor should not be the sole basis for awarding business contracts: Organisations should not award business to the lowest bidder because price has no value without quality.

Continuous improvement of the system: Senior management must be responsible for finding solutions to problems that affect quality and productivity. They should anticipate problems that arise by using control charts.

Institutional training: Management should focus on training for the organisation's employees in order to implement the philosophy of continuous improvement. Management should determine the resources necessary to train their employees to perform their jobs accurately and to a high performance level.

Institutional leadership: Senior management should train supervisors in statistical analysis methods and the philosophy of the organisation, and they should encourage employees' strengths rather than concentrating on their shortcomings.

Drive out fear and create an innovative environment: Senior management in the organisation should support interaction between the employees. The cause of fear can stem from the employees' feelings of powerlessness and professional inadequacy, resulting from job insecurity, lack of motivation and interest in work-related tasks, inadequate supervision and lack of understanding of policies and procedures. Senior management should provide security for their employees, in the form of sufficient training, structured supervision, and the appropriate tools for them to perform their tasks. If employees are treated with respect by their supervisors, this will lead to a more trusting and innovative environment.

Optimise team efforts: Senior management should maximise the deployment of employees, teams, and committees, in order to achieve the organisation's goals. Any barriers that exist between the organisation and its customers and suppliers should be broken down with collective effort; communication channels are essential to bring this about.

Eliminate unnecessary calls for increased productivity from the work force: Continuous demands for additional productivity could become an obstacle to an organisation's improvement. Senior management should focus on the methods and tools rather than purely on worker output.

Eliminate numerical quotas for the work force that substitute quantity for quality: Managers should appreciate that this approach only leads to inferior workmanship. Managers need to understand the processes within the organisation before setting unrealistic quotas.

Remove barriers that undermine employees' pride in their workmanship: Managers should establish job descriptions for every job, and ensure that suitable tools and materials are available and that every worker knows his/her role in the entire process.

Encourage education and self-improvement for everyone: Managers should use Deming's 14 points as a basis, since in order to obtain commitment to employees' self-improvement, training and education is vital. Only with this can high quality, standards are assured, and therefore education and self-improvement should be central to the organisation's ethos.

Responsibility for implementing the transformation: It is the duty of senior managers to develop the necessary culture within the organisation to bring about the required 
changes in order to introduce the appropriate TQM philosophy that will be successful for the organisation as a whole.

Another important contributor to the development of TQM is Joseph M Juran, who introduced the quality trilogy (quality planning, quality control and quality management). He argued that if an organisation intended to implement successful QM systems, it should demand quality processes along with its planning, improvement and control. Juran stated that quality is strongly linked to a customer's satisfaction with the product, and he stressed the importance of continuous quality improvement by encouraging small improvement projects within the organisation (Godfey, 1999; Bauer et al., 2006; BPIR, 2011).

Juran created ten requirements for supporting the idea of continuous quality improvement, which are as follows:

1. Awareness training in connection with quality improvement for all employees

2. Setting of clear attainable objectives in recognition of the need for improvement

3. Reorganisation of internal structures to meet these objectives

4. Establishment of training programmes in accordance with point three

5. Creation of projects to tackle existing problems

6. Monitoring and recording of progress achieved in tackling identified problems

7. Appreciation and recognition of staff successes and achievements

8. Wide promotion (internally and externally) of all quality-related developmental success

9. Statistical recording and analysis of improvements to inform future implementation and further development

10. A quality focus with a continual and upward momentum.

Juran focused on both internal and external customers, believing that everyone was important in the quality process starting from the design of the product through to the final customer (BPIR, 2006: Defeo et al., 2010).

It is also important to mention Philip B Crosby (1985), who invented the concept of 'Zero Defects', a quality improvement process based on the following four premises (as noted by Kehoe, 1996) :

1. Every employee in the organisation needs to be completely clear as to what is required of them.

2. Prevention is better than cure - through strong leadership; a disciplined workforce will ideally anticipate problems before they arise.

3. Zero defects means that any imperfection, whether in product or service, must be eliminated.

4. Quality has to be measured in order to reach a guaranteed standard of conformity of products and consistency of service.

Crosby (as noted by Saylor, 1992) also suggested the following fourteen steps to achieve improvements in quality:

1. Formal commitment to quality policy by management.

2. Each department to supply a representative to a management-led quality improvement team.

3. Analysis of present and possible future issues regarding quality issues.
4. Assess quality cost and its viability as a measuring tool for management to calculate wastage.

5. Campaign to raise consciousness of quality issues amongst all employees.

6. Institute corrective procedures through established formal channels to tackle problems at the root cause.

7. Establish a zero defects committee and programme.

8. Train all employees in quality improvement.

9. Hold an In-Service training day to address the Zero Defects issue and ensure this is attended by all employees.

10. Encourage individuals and groups to set improvement goals.

11. Encourage employee/management communication to discuss any obstacles to attaining improvement goals.

12. Give formal recognition to all participants.

13. Establish quality councils for quality management information sharing.

14. Do it all over again - form a new quality improvement team.

Finally, the ideas of Kaoru Ishikawa are of great relevance here, since as noted by Besterfield et al. (2003), Ishikawa has contributed greatly to the discussion of TQM philosophy and practice. One significant addition from Ishikawa's theoretical work is the focus on human resources. He emphasises that the seven analytical tools he devised (Pareto analysis, Cause and Effect Diagrams, Stratification, Check Sheets, Histograms, Scatter Charts, and Process Control Charts) should be circulated as widely as possible among the employees within the organisation and should be used by them in order to detect the causes of problems existing in quality processes. This would result in more efficient problem- solving within the organisation (Bauer et al., 2006).

One of the most active tools that Ishikawa produced was based on the concept of 'Cause and Effect', and the diagram he developed is used to help teams in their efforts to achieve quality improvement. The Cause and Effect diagram is useful in helping to analyse the causes of any specific problem by detecting the major and minor reasons for the main difficulty (Besterfield et al., 2003). The Cause and Effect diagram appears as Figure 3.

Considering all the TQM models, it is apparent that in order to import TQM practices into the existing QM models used within law enforcement agencies, it would be necessary to make certain adjustments. As already indicated, the hierarchy within such agencies shows a strict hierarchy with the Chief Constable at the top, and this person would need to propose and implement for formal QM policy. Subsequently, a QM team would have to be appointed to supervise organisational changes in respect of QM; and to ensure the effective monitoring of quality changes, standard measurements of quality would have to be established. Alongside these procedural changes, management would have to familiarise employees with the new quality control measures, and instructed in how to monitor the quality of the law enforcement services they provide. Furthermore, it would be necessary to formulate corrective standards, and finally, there would have to be continuous monitoring of all policing processes to guarantee their effective implementation, and thus, quality service. 


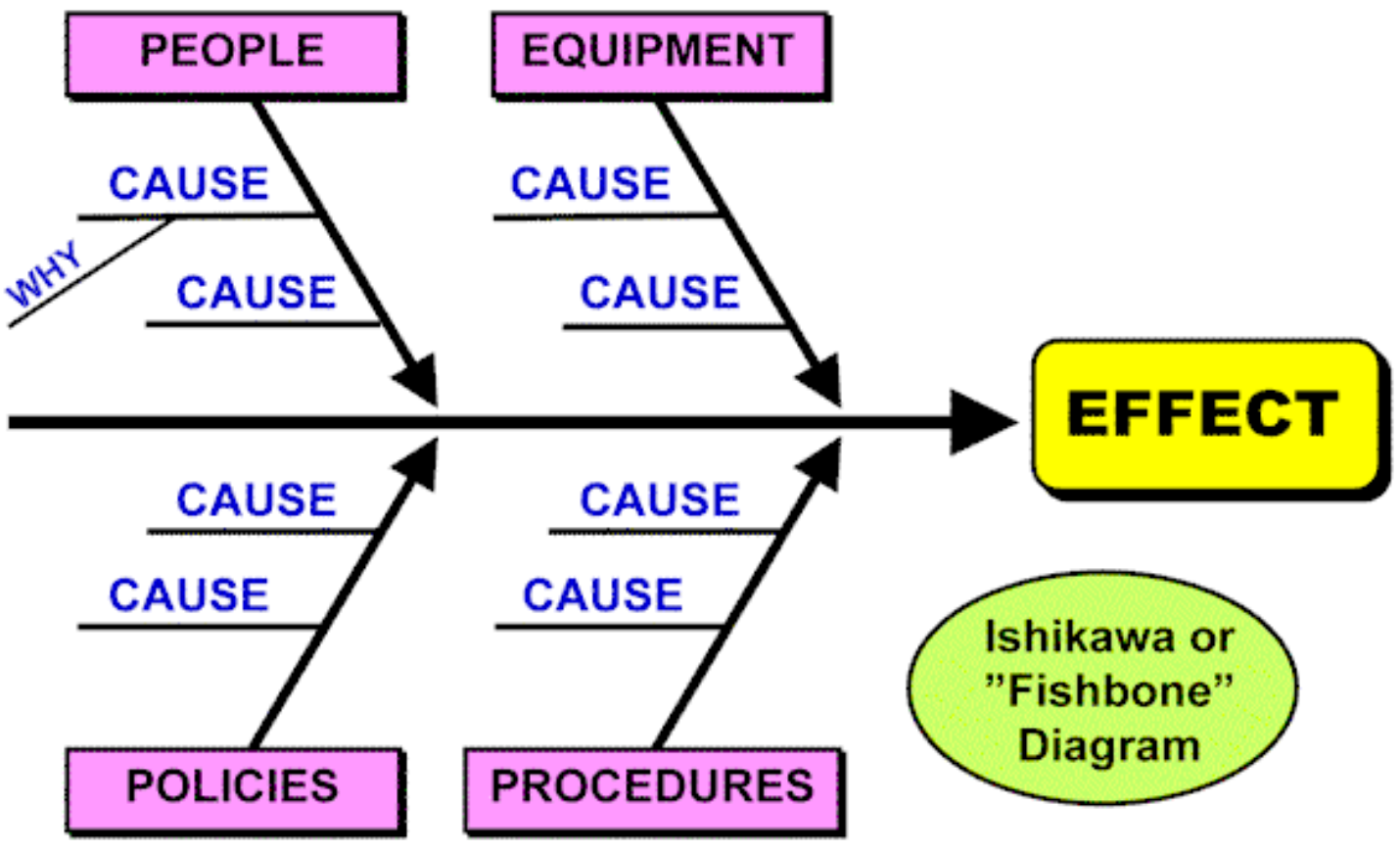

Figure 3. Cause and Effect Diagram

(by: Julia Rutherford Silvers, CSEP, accessed 2013, http://www.juliasilvers.com/embok/Guide/RSK/RiskAssessmentMgmt/causeeffect_analysis.htm)

Reflecting on the work of these theorists, it would seem that in the world of business management, whether in the private or public sectors, profit or non-profit organisations, TQM has been perceived as vitally important, especially as it has developed over a period of 60 years (Dean and Bowen, 1994), and has shown itself to be a model that has been capable of adaptation to a variety of different organisations, and of showing sustained quality improvements.

\section{TQM in the Public Sector}

As indicated before, TQM has gradually spread from the manufacturing sector to the service sector, and most recently into the public sector. In this environment, TQM is commonly used to implement QM strategies related to state-funded education, and human resources, although it has other applications within government in terms of the maintenance of public infrastructure (roads, sewage treatment, and water provision), the military, and law enforcement. Swiss (1992) suggested that one of the main reasons why TQM has gained currency throughout the public sector is that many areas within this sector have increasingly followed popular business models in terms of their administrative functions and hierarchy, thus making public sector organisations more similar to businesses than they have been in the past.

Moreover, a central argument for adopting TQM within the public sector is that it is the responsibility of good government to operate in an efficient and effective manner (Ho and Shih 2001). This entails reducing costs without denying taxpayers the services they require, for example, crime prevention, well-maintained roads, and access to schools and hospitals. Koehler and Pankowski (1996) argued that one of the main barriers to the effective use of TQM practices by governments, lies in the fact that most government employees are not trained in business-related fields or human resource management and, therefore, do not understand the TQM process.

Clearly, the public sector does present a different scenario from the traditional business environment with which TQM was initially associated, and in recognition of this, Fernandez and Ratney (2006) argue that several critical factors must be addressed if TQM practices are to succeed in public organisations. Firstly, the organisation must have a genuine need for implementing TQM practices. Secondly, it must create a plan for implementing TQM. Thirdly, it must have support from internal customers. Fourthly, management must support and understand TQM changes. Fifthly, the organisation must have the support of external customers and stakeholders. Sixthly, the organisation must have both the financial and technological resources to implement TQM. A seventh requirement is that it must actually implement the change; and an eighth requirement is that the organisation must complete more extensive changes in terms of quality. The main argument for this sequence of steps being appropriate and indeed, necessary for the implementation of TQM in the public sector, is that it outlines a plan that will help public sector officials and internal customers to understand what TQM is and how it works, thereby making it a more effective method of QM for the organisation involved.

Koehler and Pankowski (1996) suggest that the US government has had reasonable successes in its attempts to introduce the TQM philosophy and its practices within several of its departments. In this respect, it is noted that where success is not achieved, one of main barriers appears to be that few government administrators understand TQM processes and what they mean, and consequently, the application of TQM principles is not consistent across departments. This confirms the need for the eight-point plan proposed by Fernandez and Ratney (2006) since that clearly aims at raising awareness among all stakeholders. 
It is obvious from the research into the success of TQM in the public sector that the key factor in achieving effectiveness in this context is the quality of the leadership and the ability of those leading the initiative to focus on the more flexible aspects of TQM philosophy and promote these to lower level employees. Hence, leaders should be properly trained and apprised of the TQM concept in its entirety. Additionally, the research indicates that TQM must be adapted to fit the organisational cultures and practices of public sector organisations as they frequently have different aims and goals from those of TQM, and they may not be as focused on customer or client services as managements are in profit-making organisations. As a result, more concentration on other areas of the TQM process is required (Berman and West, 1995).

Such adaptation is not difficult to achieve. Indeed, there are several public sector areas beyond the government itself in which TQM has been successfully adapted to fit the needs of the public sector. These include education (Aksu, 2003), the military, and the police force. Militaries throughout the world have adapted TQM in order to create their own QM programmes, specific examples being the US Army and the US Air Force, both of which have their own TQM-based initiatives. Likewise, the police sector has also demonstrated some modicum of success in implementing TQM in police organisations to improve tasks ranging from homicide investigations to case clearance rates.

\section{TQM in the Military}

Particularly in respect of the military, as just indicated, there has been considerable success around the world in the use of TQM practices and principles. At this international level, several nations have sought to implement TQM practices in their militaries as part of an effort to decrease costs while still maintaining a strong national defence. That said, there are differing experiences in these efforts since although TQM has evidenced some success in nations with smaller militaries, it has proven difficult to adapt to large modern militaries such as the five branches of the US Military (Army, Navy, Air Force, Marines, Coast Guard) as these more modern military organisations began developing their own models and theories of quality control in the post-Vietnam War decades, and as such they are embedded within their organisational cultures.

However, whilst the branches of the US military and other large militaries around the world may not specifically implement those practices traditionally associated with TQM, to some extent, all military QM practices are based on the TQM philosophy. The US Army (2002) refers to its QM programme as Total Army Quality Management or TAQM, and this, much like traditional TQM, focuses on a specific process or series of processes in order to improve the quality of US Army operations.

This situation can be traced back to the late 1980s when the US Department of Defence instructed the branches of the US military to implement TQM practices in order to improve the efficiency and effectiveness of the way the US military was being run. In addition, while some branches of the US military (such as the Army and the Air
Force, as already mentioned) have developed their own specific QM programmes, these remain relatively similar in scope to traditional TQM practices and philosophies, thereby echoing the original ideas and motivations.

Much like the original TQM philosophies such as Deming's, TAQM involves several key aspects including: a) leadership, vision and commitment, b) mission and customer focus, c) employee empowerment, and d) continuous improvement. Furthermore, as traditional TQM philosophy, TAQM is perceived as flexible and applicable to a wide variety of military settings (US Army, 2002).

\subsection{Six Sigma in the Military}

One method by which TQM has been implemented in the US military is using Six Sigma, an alternative to more traditional TQM methods. Essentially, Six Sigma is an approach developed by Motorola in 1981, involving strategies, techniques, and tools all aimed at improving processes (Geoff, 2001; Cheng, 2008; Prajogo 2007). However, it was not until a decade later in 1995, when General Electric adopted the model and demonstrated its centrality to the successful business strategy of the corporation, that it became famous (www.pqa.net: The Evolution of Six Sigma), and since that time, it has been used in many different sectors of business (Safari Books Online, accessed 3.10.13), with substantial savings being reported by organisations that have implemented Six Sigma initiatives. Indeed, as of 2006, over US\$17 billion had been reported as savings from its use by Motorola (About Motorola University, 2005), and according to DeFeo and Barnard (2005), by the late 1990s, approximately 66\% of the Fortune 500 organisations had started to implement Six Sigma approaches in the hope of cutting costs and enhancing quality (Zu Fredendall and Douglas, 2008).

.Basically, the approach concerns the detection of errors in manufacturing and business processes and removing these in an effort to minimise variations in standards (Antony, 2008). It relies on a range of QM methods, including the use of statistics, an approach which has brought the method some criticism on the grounds of its rigidity caused by relying too extensively on methods and tools, since this directs too much attention towards the search for errors rather than developing robust procedures which themselves can eradicate the errors detected (Six Sigma, Friend or Foe, 3 October, 2013). Criticism is also levelled at the approach as one that stifles initiative through its heavy use of role-governed structures, and its consequent task demarcation (Ruffa, 2008).

This refers to the fact that in embedding itself within an institution, Six Sigma establishes an organisational infrastructure in which particular individuals with expertise in the various methods used, have special roles for implementation, and are available for advice and guidance. These individuals are known as 'champions', 'black belts', 'green belts', 'yellow belts', etc., (Harry and Schroeder, 2006). This suggests the need to 'professionalise' QM functions, and hence, can be seen as an appropriate system for the military which prides itself on operating as a professional service. It marks a move away from QM practices that are conducted by statisticians in their own department removed from the day-to-day routine of an organisation, and towards a system where, as noted by 
Harry and Schroeder (2006), an elite ranking terminology, akin to certain martial arts systems, is used to delineate a hierarchy. The system demands absolute commitment from the executive leadership who are expected to create the vision for Six Sigma implementation, and to empower other role holders by providing them with the resources and freedom to try out new ideas in the quest for quality improvement. These role holders are as follows:

- Champions. These take responsibility for Six Sigma implementation across the organization in an integrated manner. The Executive Leadership draws them from upper management. Champions also act as mentors to Black Belts.

- Master Black Belts. These are identified by champions, act as in-house coaches on Six Sigma. They devote $100 \%$ of their time to Six Sigma. They assist champions and guide Black Belts and Green Belts. Apart from statistical tasks, they spend their time on ensuring consistent application of Six Sigma across various functions and departments.

- Black Belts. These operate under Master Black Belts to apply Six Sigma methodology to specific projects. They devote $100 \%$ of their valued time to Six Sigma. They primarily focus on Six Sigma project execution and special leadership with special tasks, whereas Champions and Master Black Belts focus on identifying projects/functions for Six Sigma.

- Green Belts. These employees take up Six Sigma implementation along with their other job responsibilities, operating under the guidance of Black Belts.

Additionally, in some organisations, there are Yellow Belts, accorded to employees with basic training in Six Sigma tools, White Belts who are locally trained in the concepts but not involved in project teams, and Orange Belts who are used for special cases (Mikel et al., 2011).

This whole notion of rank seems to fit well with the culture of military organisations where individuals accept status as part and parcel of the job and are happy to participate in role-demarcated activities. Indeed, the approach has yielded significant results, promoting improved quality control within both the manufacturing and services sectors within the US Army (Wellman et al., 2003). The main argument behind the use of Six Sigma is that it is more effective than TQM practices in creating positive results. Moreover, Wellman et al. (2003) claim that the practices of Six Sigma already closely resemble quality practices in the US military (Levy, 2010), thereby further emphasising the notion that rank and strong role demarcation are seen to be important in ensuring improved quality.

This supports research that indicates that the reason why other branches of the US military have had significant problems in implementing TQM practices is simply because they already have effective QM practices in place that have not needed to be overhauled or reengineered. For example, the US Air Force (USAF) developed its own QM programme called QAF (Quality Air Force) in the 1970s and 1980s. In developing this programme, the Air Force did consider TQM practices and philosophies, but it was decided that these were illsuited to the precise organisational context for several reasons. Firstly, the military was neither profit, nor customer service-driven. Secondly, soldiers were crisis- driven in that they were confronted with life-threatening issues on a day-to-day basis and needed to be able to make spur-of-the-moment decisions on what actions to take. TQM was perceived as limiting in these circumstances, and not flexible enough to allow soldiers to provide quality service without further endangering their lives (Rinehart, 2006).

While TQM-based practices in the military have had varying success, this may be partially attributed to the fact that the military works as a branch or sub-section of the government and, therefore, must operate within the confines and limitations of government quality management practices. If the military is adopting TQM practices yet the government organisation responsible for managing the military (e.g. US Department of Defence, British Ministry of Defence) is not adopting TQM practices, difficulties can be created in implementing TQM effectively, since as has been indicated in previous research (Deming, 1986; Besterfield et al., 2003), a topdown approach whereby leaders are trained in TQM philosophies and practices first and then deemed responsible for training employees and lower level managers, is more effective in ensuring that TQM is effectively implemented at all levels of an organisation.

\section{TQM in the Police Force}

It might be appreciated that police organisations resemble military institutions in many ways, especially in their concentration on rank and hierarchy, and that the experience of police organisations in adopting TQM practices might therefore mirror those of the military. However, in reality, the police sector has been considerably more successful than the military sector in implementing TQM philosophies and practices. Arguably, the main reason for this situation is that the police sector has more freedom than the military in that it has less direct governmental supervision. Whereas the supervision provided over the military by the US Department of Defence or the British Ministry of Defence is more specific and focused on military policies procedures and practices, the US Department of Justice (and each individual state's justice department), and Scotland Yard, take a less direct and focused approach to managing their nations' police forces, thereby allowing the police sector to act as the primary guide in the creation of QM practices with little interference from their supervising government agencies (Brain, 2010; Jones 2008).

Quality control in policing is an important requirement because the general public need to respect the police, local communities need to have their particular security requirements met, and police officers themselves are regularly placed in situations where their own safety is at risk (Caless, 2007). Standardised operating procedures are therefore, crucial since these reduce the potential risk to both the public and the police.

Mawby and Worthington (2002) state that increased attention to quality control and TQM in policing has allowed police departments throughout the Western Hemisphere to market themselves as a service rather than as agents of the government, which is the more traditional view. In addition, Greasley (2004) suggests that TQM offers an effective solution for police departments looking 
to improve processes and procedures as it involves simple concepts that are easy to understand for officers with little management training. Another reason why the police sector has been more successful than the military in implementing TQM is that law enforcement and policing are more service-driven than the military, and include components of other service sector industries such as social work, within their overall aims and objectives.

TQM practices have been used to improve a wide range of tasks and aspects within police forces internationally. These tasks have ranged from improving homicide investigations to community-based policing (this involves working with the people within a local authority to decrease crime and building a working relationship with the residents living within a local authority).

However, it is noted (Riley, 2009) that the implementation of TQM-type techniques within policing is quite different from the way they would be introduced in other public sector organisations, and indeed within the private sector. A fundamental reason for this is the fact that any shortcoming in the quality of the policies and procedures may jeopardise the lives of officers. Riley (2009) argues that TQM in police organisations is characterised by several key features including: a) a focus on integrated management, b) detailed QI processes, c) a top-down management focus, d) a continuous focus on quality, e) a focus on community and organisation-wide improvements, and f) acting in a proactive manner to new situations rather than in a reactive manner.

Riley (2009) also argues that there are several critical management techniques required for the effective implementation of quality initiatives in police organisations including: timely intelligence, rapid response, follow-up, and accountability. This essentially means that police management is responsible for ensuring officers have the correct intelligence about crime in time to use it, the ability to respond to crime rapidly and to follow up on crimes once they have occurred, and finally, that officers and criminals should be held accountable for their actions. The ultimate goal of the police is to respond appropriately in order to solve and prevent crimes, and consequently, these management processes are well suited to police organisations.

Donnelly et al. (2006) argue that several traditional TQM models such as SERVQUAL have been successfully used to evaluate TQM in the police sector. For example, in a study of the Strathclyde (Scotland) Police, it was discovered that for the most part, TQM was an effective QM system for the police force with the sole exception of customer focus (Donnelly et al., 2006). This appears to be a specific weakness related to public sector organisations such as the police or the military in that their focus on non-customer related tasks such as homicide investigations or military actions, means that TQM practices fail when it comes to their client orientation.

However, one of the main arguments surrounding the use of TQM by the police sector is that the activities associated with it provide law enforcement with the tools necessary to evaluate police practices in order to ensure that they are serving their customer base in an efficient and effective manner by meeting their goals and aims of preventing and solving crime. Therefore, whilst the customer orientation at the individual level is lacking as indicated in the previous paragraph, at a community level it is very much present (McLeod, 2003).

Another argument for the use of TQM is offered by Tari (2006), who observes that one of the primary effects of TQM models such as the EFQM Excellence Model, on police practices has been to reduce inefficiency in terms of both employees and service processes.

Selen and Scheppers (2001) state that TQM is a necessary part of designing successful law enforcement systems and providing effective and efficient service to the police department's customer base (residents within the local authority). And one of the key ways in which TQM has been effectively used within the police force to provide security to citizens, is seen in the improvement of the methods by which homicides are investigated. In this respect, Timothy Keel, an FBI (Federal Bureau of Investigation) analyst argues that a significant difference has emerged in the number of homicides being 'cleared' or solved by homicide detectives and the number of convictions for homicide as a result of new TQM practices in US police departments. Furthermore, other issues have been identified by the FBI such as how detectives are selected to work homicide cases, how cases are handled, caseloads, and how evidence is collected and gathered (Keel, 2008).

Keel (2008) identified several potential solutions for the low clearance versus conviction rates in homicide departments in the US, these being:

- Limiting detectives to working fewer homicides each year.

- A requirement that a minimum of two, two-officer homicide teams report to the crime scene.

- A requirement for case reviews to be submitted to department captains within 24-72 hours of the initial investigation.

- The elimination of paper case management systems and the introduction of computerised systems.

- The use of standardised forms for car stops and neighbourhood canvassing after a homicide.

- The introduction of a Comptstat-style quality control system.

- The building of strong relationships with medical examiners (forensic pathologists) and criminal prosecutors.

- The elimination of the rotation of homicide detectives to other departments.

- An allowance for a certain amount of overtime hours per pay period so that cases may be resolved quickly.

- The introduction of Cold Case Squads to deal with unsolved homicides.

- The use of modern and up-to-date investigative tools.

- Teamwork.

These recommendations indicate that it is much simpler to adapt police organisations to the use of TQM practices than many researchers in the field seem to think. They also show that if such practices are not already in place, then there is a significant need for TQM in law enforcement since some of these are no more than common sense. Clearly, some tools may be need to be adapted to work within police organisations, but with such effort, TQM can have a positive impact and improve how police organisations function. 
Another critical area that has been addressed by researchers exploring the potential for implementing TQM philosophies and practices in the police sector is that of shared leadership. This concept embodies the notion that leadership within a given police force should be shared by different levels of management. Theoretically, this method of operation would give a shift supervisor who is on the streets with his fellow police officers as much right to have an input in the leadership process as police administrators. Steinheider and Wuestewald (2008) argue that what they term 'participative management' is one of the main ways in which TQM is being adapted in the police sector, and that so far, it has been reasonably successful.

At the international level, it is observed that TQM philosophies have been adapted to the police in many ways. For instance, the German police forces have adapted the principles of 'New Public Management' (NPM). This is a TQM-based process that separates the different aspects of popular TQM models such as SERVQUAL and EFQM into what are termed, competencies. Quality of performance and service are rated according to how police departments perform in specific areas. This TQM tool has allowed police departments in Germany to improve their service in areas ranging from investigations to how suspects in a crime are interrogated (Ritsert and Pekar, 2009; Coleman, 2004).

Simultaneously, TQM has enabled police forces at the international level to restructure and reorganise their departments so that they are able to work more effectively with modern technology and to cope with their prosecution of modern crimes such as identity theft and cybercrime. Pritchard et al. (2009) suggest that TQM practices and philosophy can be used to improve police organisations' goals and objectives, to more clearly define mission statements, to improve employee training, and to improve the quality of customer/client assistance. A second observation is that TQM has allowed police departments to develop processes that not only focus on their external customers, but also accord more attention to their internal customers (Armeli et al., 1998).

Armeli et al. (1998) demonstrate that the world's police organisations use TQM in a wide variety of ways either by adopting traditional TQM models such as SERVQUAL, or by developing their own models designed specifically to meet the needs of the modern police force. TQM philosophies and practices are more easily adapted to police organisations than they are to other organisations within the public sector.

While some critics have argued that TQM is not a suitable method of improving quality in policing organisations, research does confirm that it can be every effective both in providing a set of guidelines which allow police organisations to develop their own programmes, and in presenting a pre-existing set of tools that can be used for quality initiatives, thereby giving police forces a choice in how they proceed. Clearly, there are some areas of policing where TQM has been perceived as more successful than in others (e.g. community policing vs. evidence gathering), but in general, it has proven to be an effective tool for improving the quality of police practice.

However, it is essential that the unique aspects of policing are borne in mind in the choice of TQM practices, and this implies a focus on the service-based TQM models, and on improving quality in areas that involve the safety of police officers and residents within the local community. Obviously, in other public sector organisations, internal employees and external stakeholders are relatively safe from physical harm and such considerations have little meaning, but in policing this is not the case, and attention must be directed to the ways in which officers interact with the public, regulations surrounding weapons use, arrest procedures, and investigative procedures, among other aspects of policing. By using quality improvement methods such as TQM in these organisations, policing can be made safer for both internal and external users of the service. The big question that remains in this respect is whether any particular TQM model is more suitable than another is for the policing environment, and in order to reach a conclusion in this respect, it is necessary to appraise the various models available and that might compete for the position of the best fit. The following section does this.

\section{TQM Models}

As has already been indicated, TQM extends to a variety of models, a discussion of which is presented in this section. The most appropriate starting point in this respect is the founding of the International Organisation for Standardisation (ISO) in 1947, which has since published over 18,000 international standards including standards for agriculture, construction, mechanical engineering, medical devices, and developments in information technology - to name but a few (Russell, 2000). And the Draft of the International Standard ISO 9000:2000 has meant that the debate on improvements and excellence in the business and service sectors has continued. The concern is, which is more important - the introduction of the standard ISO 9000:2000 or the continuing search for the Excellence Model (Russell, 2000; Fotopoulos et al., 2010).

These additional models developed out of a need to eliminate confusion felt by lower level managers and employees who were often uncertain as to what the concept of total quality management meant and were hesitant to implement total quality changes within the organization. Soltani and Wilkerson (2010) suggest that more detailed models such as; ISO 9000-2000 were a response to this confusion and allowed upper level managers to implement a system that was better suited to giving detailed explanations to employees and lower management.

The relevant standard for assisting organisations with QM is ISO 9000:2000, which describes the essentials of a $\mathrm{QM}$ system. In concentrating on QM, this standard has been strengthened by the introduction of eight QM principles (Russell, 2000). Terlaak and King (2006) argue that these ISO 9000:2000 quality standards have been effective in improving the performance of certified organisations because the certification in and of itself makes the organisation more credible in the eyes of customers or clients. And not surprisingly, there has been much discussion and research on the effects of ISO certification, since stock market evaluation reflects the benefits to companies of obtaining this. One example of such research was that conducted by Vloeberghs and 
Bellens (1994, cited in Russell, 2000) which attempted to demonstrate the effects of QM in accordance with IS0 9000:2000 among a group of quality managers in certified companies in Belgium. After undertaking a survey approach, the researchers noted four important internal effects as follows:

- Strongly developed system of procedures

- Clearly defined responsibilities and obligations

- Reduced improvisation

- Organisational structure becomes apparent

From these findings it is apparent that there is no mention of the financial implications of introducing the QM programme, the emphasis seemingly being placed on external effects, and specifically, the improved level of trust between the companies and their clients. In addition, there is noted improvement in the better service that customers received and the commercial benefits to the companies that resulted from this (Russell, 2000). Terlak and King (2006) have also found that the use of ISO9000:2000 quality control standards encourages the reduction of asymmetrical information in an organisation's supply chain which in turn is helpful to an organisation in increasing its ability to compete with other organisations.

Naturally, given the ongoing nature of the development of the ISO 9000 standards, there are different versions including those released in 1994 (ISO 9000:1994) and 2000 (ISO 9000:2000), but research has demonstrated that the 2000 edition is more effective in TQM practices than previous editions. Martinez-Costa et al. (2009) suggest that the main reason for this difference in outcome is that ISO 9000:1994 focused on performance as a reflective construct whereas ISO 9000:2000 focuses more on performance as a formative construct in QM.

Therefore, it can be assumed that certification and QM according to ISO 9000:2000 has brought many benefits. Well-defined working procedures and clear lines of responsibility are the obvious and beneficial results from this. The development of ISO 9000:2000 also encouraged other QM-focused organisations to begin developing their own models of quality standards, and during the 1980s and 1990s many frameworks were created, but two of the most popular appear to have been the EFQM Excellence Model, and SERVQUAL. Many of the organisational or field-specific TQM models are based on one of these blueprints.

Both the EFQM and SERVQUAL models have an intense concentration on the customer. Consequently, they encourage flexibility, attention to detail, and continuous improvement over time, as opposed to promoting sudden change. The philosophies underpinning these two approaches centre on the need to allow employees a period of adjustment so that implementation of change is done with thought and understanding, and also on the need to actively involve both internal and external customers in the QM process. Through this strategy the company is able to develop reciprocity between itself and its customers.

The European Foundation for Quality Management (EFQM) began over 20 years ago with the intention of promoting international co-operation among European companies to develop a management tool that would enhance the competitiveness of their respective organisations (Bou-Llusar et al., 2009). The EFQM went on to create the EFQM Excellence Model with the following objectives:

- To stimulate and assist management teams in adopting and applying the principle of organisation;

- To improve the competitiveness of European Industry;

- To close the gap of competitiveness between European and USA and Japan (Ehrlich, 2006; EFQM, 2012)

The importance of the EFQM Excellence Model is that it is flexible, reflecting an approach that recognises that there are many ways to achieve excellence in the different performance areas of QM (Russell, 2002; Hakes, 2007). There are nine criteria to be considered within the model, and these cover all branches of an organisation's operation, including significant sections that can be found in any organisation, such as leadership, people, policy and strategy, partnerships, and resources. Additionally, the model contains processes and a sub-set of results - people results, customer results, impact on society results, and business results (Ehrlich, 2006). These approaches allow a progressive assessment of excellence to take place.

The EFQM focuses on the three traditional areas of TQM, these being, people, processes, and performance. These areas encourage those who implement TQM philosophies and practices to focus on people and processes in order to improve performance (Steed et al., 2005). The components or criteria of the EFQM model can be divided into two distinct segments, enablers, and results. Enablers are processes that allow organisations to determine results, and include: a) leadership, b) people, c) policy and strategy, d) partnership and resources, and e) processes. Results include: a) people results, b) customer results, c) society results, and d) key performance results (Steed et al., 2005; Gale and Wood 1994).

By dividing the components of the EFQM into enablers and results, it is possible to see how the process works and in fact, how the results can be applied comprehensively throughout an organisation. It also allows the user to gain a greater understanding of how each individual component of EFQM influences the results of the EFQM analysis.

The EFQM comprises a set of criteria that, when implemented consistently and faithfully, represents different areas of organisation within each enterprise. The EFQM recognises that the satisfaction of everyone is involved in the process of achieving excellence. Customers, employees, and society in general, all directly benefit when excellence is achieved by an organisation (Ruiz-Carrillo and Fernandez-Ortiz, 2005). This excellence is brought about through effective leadership, robust management, and control of available resources, as well as a strong understanding of the processes involved. When all these factors are present, it is likely that promising outcomes will emerge.

In order to assess which of the two approaches - either the competitive (ISO) or the co-operative (EFQM) - is the more appropriate, the basic principles of each method will now be considered. Clearly the principles on which each model is based acknowledge the importance of customer focus and leadership. The two models are compared in Table 1.

Upon closer examination, it is clear that ISO 9000:2000 is more concerned with process and sustained improvement. However, the reliance on supplier 
relationships shows a gradual convergence towards the Excellence Model. Nevertheless, differences are obvious. The Excellence Model takes a more flexible view on partnerships and is also concerned with innovation and responsibility towards the public. In both models however, Deming's influence is clearly apparent, particularly in the 'plan-do-check-act' cycle. If these models are implemented sensibly they can make a valuable contribution to any organisation's improvement of its QM. However, if they are introduced without the necessary understanding of the company culture within which they operate, then they will fail to achieve the goals they wish to achieve.

The work of the ISO has fostered a tremendous range of international standards and in particular 9000:2000 which has had a bearing on QM generally. The impact of ISO certification is undoubted as was revealed by Vloeberghs and Bellens (1994) in their Belgian study that demonstrated improved practice throughout the organisations included in their survey (Russell, 2000). However, it is equally important to note that the responsibility of the EFQM and its Excellence Model has been to introduce a more dynamic approach that takes account of a far broader view of each organisation's work and places it in a societal context (Ehrlich, 2006). In the debate comparing the two models it is difficult to make a clear judgment as to which is the better, since as can be seen, the claims of each are equally valid, depending on the context and the culture in which the models are operated.

Table 1. A Comparison of the Fundamental Excellence Concepts of ISO 9000-2000 and the EFQM

\begin{tabular}{|ll|}
\hline The Eight Principles of ISO 9000-2000 & The Fundamental Concepts of the EFQM \\
\hline Customer Focus & Customer Focus \\
\hline Leadership & Partnership Development \\
\hline Involvement of People & People Development and Involvement \\
\hline Process Approach & Management by Processes and Facts \\
\hline Systems Approach to Management & Continuous Learning and Innovation \\
\hline Factual Approach to Decision Making & Leadership and Constancy of Purpose \\
\hline Mutually Beneficial Supplier Relationships & Public Responsibility \\
\hline & Result Orientation \\
\hline Source: Russell (2000)
\end{tabular}

Source: Russell (2000)

Bou-llusar et al. (2009) suggest that the EFQM model is comparable to other current models of quality control. In their comparison of the EFQM model and the Malcolm Baldridge National Quality Award (MBQNA) model, it was found that while both models provide standard TQM process models for quality control, the EFQM is more efficient and effective than the lesser known MBQNA model. This indicates that the EFQM has become well known, specifically due to its efficiency and effectiveness.
In 1985, Zeithaml et al (1990) designed a Service Quality Framework tool entitled SERVQUAL. (Buttle, 1996; Carr 2002) in order to measure the quality of service solely from the customer viewpoint. This model is based on a scale of measurement which considers ten different aspects of service quality, these being: Access, Communication, Competence, Courtesy, Credibility, Reliability, Responsiveness, Security, Tangibles, and Understanding the Customer as shown in Figure 4.

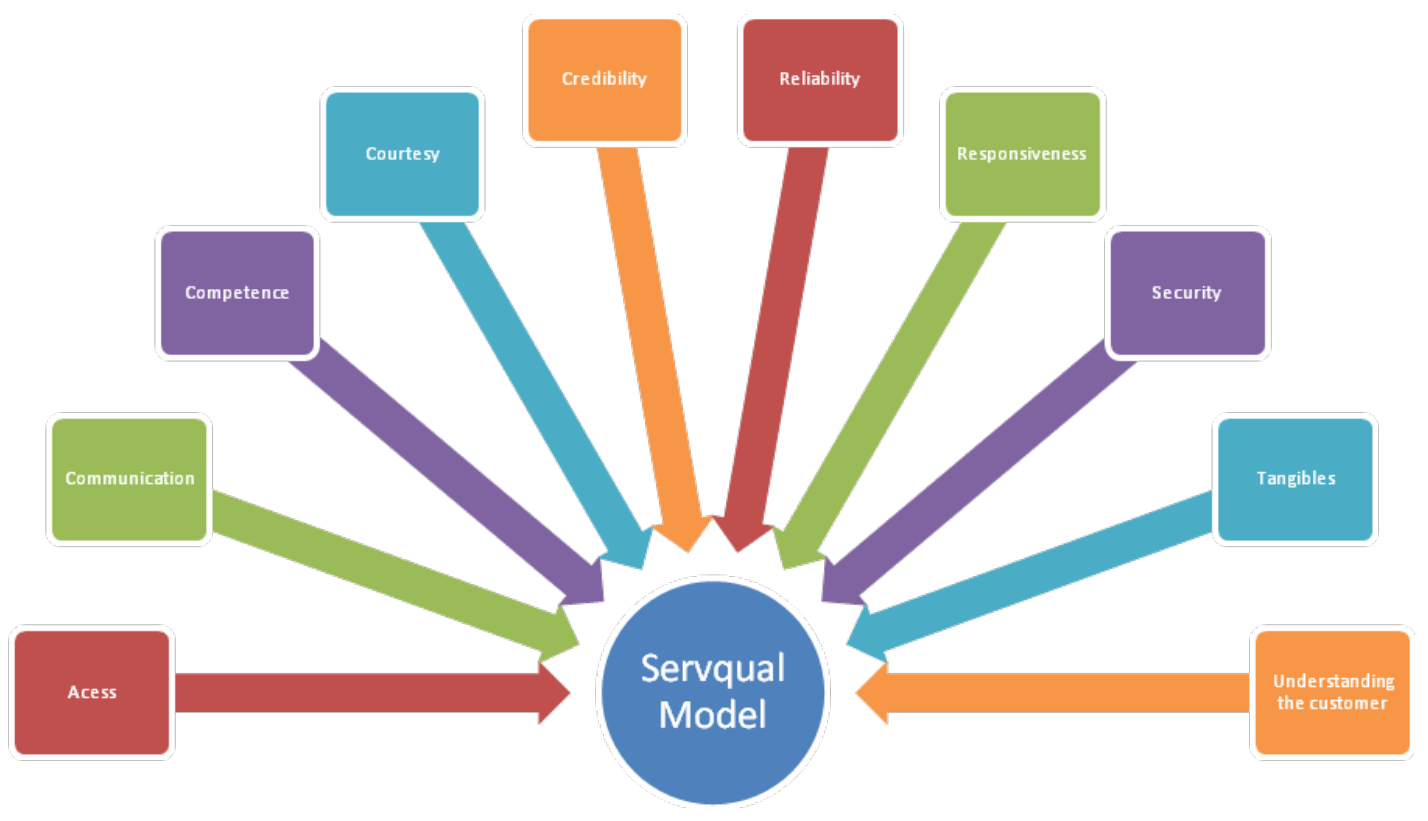

Figure 4. SERVQUAL Model (Buttle, 1996:9)

Clearly, each of these ten dimensions has its particular focus as follows:

- Access: the availability of the service to the customer.

- Communication: how customers feel about being updated with relevant developments.
- Competence: how customers view the employees' (or services) role in carrying out the expected task associated with the service.

- Courtesy: the politeness of staff and the presence of 'smooth interaction' when engaging with the service. 
- Credibility: the customer's confidence in the service because of his/her past experience and the provider's reputation.

- Reliability: the customer's assessment of whether the service can be 'trusted' to perform consistently as per specifications.

- Responsiveness: the ability of the employees to respond to the customer in a timely and effective manner.

- Security: the customer's confidence in the service's ability to provide a safe environment for business to take place (the term 'safe' could be used to describe a private cubicle to discuss business, adequate security for online payments or a secure data protection policy, amongst other things).

- Tangibles: the 'physical' aspects of the service being provided such as manufactured goods or medical care.

- Understanding the Customer: the service's ability to provide bespoke options to customers in order to meet their individual needs (Parasuraman et al., 1990).

The way the SERVQUAL tool works is in the form of a questionnaire that probes the ten different aspects of service quality. Customers are asked to complete the questionnaire and from the answers, the gaps between customer expectations (what a customer actually wants) and service perceptions (what a service thinks a customer wants), are identified with the aim of 'closing' the gaps, and thus reducing the discrepancies between the expectations of the customer, and the perceptions of what the customer wants from the service (Stodnick and Rogers, 2008). SERVQUAL was identified by Szwarc (2005) as an effective means of assessing what customers thought about the quality of a specific businesses products or services.

By the early 1990s, however, this model was refined by Zeithaml and colleagues, so that it contained just five aspects, these being: Reliability, Assurance, Tangibles, Empathy, and Responsiveness (Buttle, 1996). This reworked framework came to be known as the RATER framework (hence the layout of the service quality aspects). It should be noted that the Assurance and Empathy aspects are the two areas where the remaining original seven qualities can be found (Buttle, 1996).

One of the advantages of the SERVQUAL framework is that it encourages detailed customer input across a variety of different quality areas in a single exercise. Also, as the framework is not service-specific, it can be used in a variety of different sectors (Seth et al., 2004), such as, retail, healthcare, education, and policing.

The SERVQUAL framework allows services to focus on improving a specific area (or areas) and can be used as a comprehensive statistical analysis tool which enables the user to interpret the data accordingly. Also the questions asked in the questionnaire can be tailored to what the user wants to measure, so that the responses will be relevant to the question that has been posed. This allows the user to significantly reduce or arguably eliminate random, unusable customer responses that would reduce the reliability and validity of the questionnaire and could effectively skew the results that would have been gathered.

Furthermore, the SERVQUAL framework is an excellent way of obtaining an image of how the service is performing at a specific moment in time, which would allow the user to create a 'milestone' to measure the improvements made based on the responses to the initial administration of the questionnaire. However, some of SERVQUAL's strengths are also part of its weaknesses. Because the framework operates on a 'snapshot' basis, it does not take into account the economic climate at the time the exercise is conducted, and therefore, the model does not offer a means of predicting how effective a service will be in the future. Essentially, it can only be used as a tool for improvement, and not as an indicator of what is to come. Additionally, the framework is not able to explain external factors affecting service quality as it focuses on customer responses only (Ladhiri, 2009).

Furthermore, it can be said that the lack of 'openended' or 'free form' questions pigeonholes customer responses, and hence, one does not necessarily obtain a true or accurate picture of customer representation, as the questions would have undoubtedly been constructed either by the service itself or a representative of the service (such as a consultant) but in either event, not by a customer.

It is this that leads to another criticism that has been made by other researchers (Buttle, 1996), which is that the SERVQUAL framework is very complex (possibly even too complex), and has to be administered with professional precision for the exercise to be conducted correctly and for the results to be meaningful (The Scottish Housing Register, 2011). This means that not only would a service require the resources to put the framework into practice, but it would also require someone with expertise in the area to oversee the exercise, which is an additional resource. This is simply not costeffective for organisations that wish to improve quality without significantly increasing costs.

Moreover, the criticism that the questionnaire is unduly biased (by design) in the favour of customers who do not necessarily know about the market in which a particular service operates, and that the responses that they give are generated by personal feelings rather than informed objective understanding, is a valid one. This collection of subjective data may encourage companies to provide services or products that are not necessarily wanted by the masses (Maklan and Phillipp, 2011).

There are many arguments about the extent of the success of SERVQUAL but on the whole, the RATER model has proved to be successful in improving relationships between organisations and their customers. In fact, the greater amount of debate regarding SERVQUAL has revolved around how researchers implement it rather than its reliability. The major critic of SERVQUAL is Francis Buttle (1996), who suggests that SERVQUAL does not take into account established economic, statistical, and psychological theories (RuizCarrillo and Fernando-Ortiz, 2005). However, Luis Lages argues that customer decision-making is more abstract, and he seems to prefer the SERVQUAL model which places more emphasis on an appreciation of customer satisfaction that is based around social values. In the public services it would appear from a number of SERVQUAL evaluations that have been undertaken, that reliability and validity have been uneven. For example, the evaluation of SERVQUAL in the research library at Texas A \& M University in 1995 showed that users of the facility have different ways of thinking about library 
services that show important differences for acceptable library performance and that brings the SERVQUAL model into some question in this context (Cook and Thompson, 2000).

In the case of the evaluations of many call centres that have been undertaken, it has been shown that the reliability of customers' perceptions of the service they receive is difficult to gauge effectively. This is mainly because the service delivery in a virtual organisation such as a call centre differs from the traditional face-to-face service provision within more traditional organisations (Staples et al., 2003). For this reason, the SERVQUAL model is shown to be inconsistent in evaluating customer satisfaction.

In a study conducted by Seth et al. (2004), a review of the different characteristics of 19 service quality models was made, and from this it was found that that were at least six key elements that were common to all the different models. These elements can be defined as: customer assessment of quality, customer feelings of competence in the service, customer perceptions of service, customer expectations, customer satisfaction, and the customer's judgment of the service being 'value for their money'.

The customer's assessment of quality deals with how customers view the service that is being provided, that is to say, whether it is up to the standard expected, or whether expectations were not met. Competency focuses on how confident the customer feels about the service being able to deliver what was agreed upon and its ability to display sound knowledge and communication with the customer when necessary. Perceptions of service deals with the reputation that the service may already have, either through the customer's previous experience, or through 'word of mouth' advertising, both of which predispose a certain customer expectation. What is expected from a service (success or failure) can vary depending upon the perception of the customer.

Customer appreciation deals with how satisfied the customer feels with the service that has been provided. Getting this information allows services to see why customers return (or indeed why they do not). Finally, there is the value for money element in which customers essentially choose whether or not the service 'is worth it', for the amount that they are paying. However, it must be noted that not all services would operate in this way (healthcare and policing, for example), as their customers are non-paying. Nevertheless, there would be an expectation for such service providers to fulfil their duties accordingly as they are funded to do so (often through government resources).

Given that the identified (but quite possibly not exhaustive) six elements are customer focused, it would seem to suggest that the 'primary' and 'universal' element of the service quality models examined is the customer. Hence, it is reasonable to suggest that this primary element would also be found in other models not mentioned within the study, and indeed in models that are yet to be created.

One such model comes in the form of a badge of approval, the Malcolm Baldridge National Quality National Award (MBNQA) which is issued to US companies on the basis of satisfaction of certain criteria. Specifically, these relate to: improvement of organisational practices, information sharing and communication, and customer service. The MBNQA is less sophisticated that EFQM, SERVQUAL, and ISO9000 , functioning in the main as a series of guidelines. In this respect, it can be observed that the guidelines do not conform with those in TQM models.

The Quality Trilogy proposed by Juran suggests that three core elements are required in any effective QM model, these being: quality planning, quality control, and quality improvement. Quality planning requires the creation of a strategy to enable the company to realise its quality standards, quality control relates to the set of measures used to monitor their quality, and quality improvement concerns the various techniques and strategies devised and implemented to respond to feedback from all stakeholders and enhance the quality of products and or services (Juran, 1995).

Clearly, the creators of the various quality models in existence have identified 'the customer' as an integral part of their frameworks due to the customer's role in assessing service performance. As the TQM philosophers believed, if service delivery is poor, then customers will not be interested in purchasing the service, and will instead, look elsewhere for a service that is able to meet their needs and expectations. In effect, this relationship places customers in a very powerful position, since their refusal to use a service ultimately results in that service being considered to have failed. Consequently, service quality models can be seen to place the need to satisfy the customer as a central theme, and to include mechanisms by which efforts to create such satisfaction, and levels of satisfaction reported, are constantly monitored to ensure a high level of quality and performance.

As stated previously, this is what happened in the US when competitors from other countries began to develop quality standards higher than their own, and when the US market share in various fields was seen to decrease as a result of customers abandoning American products in which they had lost confidence, in favour of the better service quality that was being provided by foreign manufacturers (Ladhiri, 2009).

In addition to the TQM philosophies, there is also the Total Quality Service (TQS) approach, which is itself based on the EFQM and SERVQUAL models, although it is not particularly well developed. This focuses more explicitly on the customer, and has 12 components, which are: a) top management commitment and visionary leadership, b) human resources management, c) technical systems, d) information and analysis systems, e) benchmarking, f) continuous improvement, g) customer focus, h) employee satisfaction, i) union intervention, j) social responsibility, $\mathrm{k}$ ) serviscapes, and l) service culture (Sureschandar et al., 2001).

In fact, this model appears to be more a blending of the elements of EFQM and SERVQUAL rather than a truly unique model. However, the TQS model does clearly illustrate how previous models can be utilised to develop new models that have the capacity to more effectively serve specific business sectors.

While SERVQUAL and EFQM both include customer focus within their purview, neither model has included both internal and external customers. In the modern market, whether one is considering service provided in the public or private sector, both internal customers (e.g. 
employees) and external customers (e.g. clients, the general public) must be included in any analysis of quality and performance, since it is argued that the reciprocal relationship existing between them can have a significant influence on service quality.

It can be understood that the idea of business excellence is at the heart of all the models of TQM discussed so far. This embodies the notion that stakeholders should be offered goods or services that meet, or extend beyond, specified quality standards. Quality management systems are, therefore, essential to guarantee quality control, quality improvement, and quality planning. Both Juran (1995) and Deming (1986) believe in the criticality of the principle of business excellence as a motive to guarantee the realisation of quality standards. Similarly, they argue for the need for businesses to be continuously improving themselves through the use of QM practices and procedures. In this respect, there is a need to focus on both the process of QM and the particular components which are involved within it (for example, customer focus). Hence, a robust QM should contain specific steps and procedures to allow the achievement of business excellence. As observed by Peters and Waterman (2004), such a model emphasises the value of producing a quality output and encourages all efforts in this regard, including managerial efforts to be sufficiently flexible that quality initiatives can be tailored to organisations' individual situations.

\section{Summary}

It has been shown in this article what the concept of TQM entails, and how the various practices and procedures associated with the operationalisation of the TQM philosophy have evolved over the past decades. This means that an idea for quality improvement that was originally tailored to the manufacturing industry in the private sector, has now become accepted as having a contribution to make in a services context in the public sector. More specifically, it has been indicated how security organisations like the military and the police can benefit by QM approaches, albeit that those approaches might not be exactly the same as those proposed in the original TQM model.

This model is presented accepting that the literature is not complete and contains shortcomings. One instance of this is the fact that some of the studies published and discussed, were undertaking before to 2004 and as such, their QM practices may have evolved, and the current picture may be different. A second limitation identified in the review was the lack of literature concerning QM in the realm of law enforcement, the military, and the public sector in general. Hence, it was hard to establish whether QM practices were actually in evidence in these contexts, and if so what degree of effectiveness was reported.

\section{References}

[1] Aguilar-Saven, R.S. (2004) 'Business process modelling: Review and framework', International Journal of production economics, vol. 90, no. 2, pp. 129-149.

[2] Agus, A. (2004) 'TQM as a focus for improving overall service performance and customer satisfaction: An empirical study on a public service sector in Malaysia', Total Quality Management \& Business Excellence, vol. 15, no. 5-6, pp. 615-628.

[3] Ahmad, K. \& Kimberly, M. (1992) 'Implementing total quality management at the US Department of Defence', Total Quality Management, vol. 3, no. 1, pp. 31-46.

[4] Aksu, M.B. (2003) 'TQM readiness level perceived by the administrators working for the central organization of the Ministry of National Education in Turkey', Total Quality Management and Business Excellence, vol. 14, no. 5, pp. 595-608.

[5] Al-Kaabi, N.R. (2007) 'Police Education and Training in Qatar: A Comprehensive Comparative View', Police Education and Training in a Global Society, p. 33.

[6] Anderson, J.C., Rungtusanatham, M. \& Schroeder, R.G. (1994) 'A theory of quality management underlying the Deming management method', Academy of Management Review, vol. 19, no. 3, pp. 472-509.

[7] Andrei, D., Ratiu, L., Otoiu, C. \& Chirica, S. (2012) 'Professional performance within a Romanian police force in the context of change', Procedia-Social and Behavioral Sciences, vol. 33, pp. 657-661.

[8] Anon (2011) The EFQM Excellence Model, vol., [Online]. Available from:

http://www.efqm.org/en/tabid/132/default.aspx (Accessed: 14 April 2012).

[9] Antony, J. (2013) 'What does the future hold for quality professionals in organisations of the twenty-first century?', The TQM Journal, vol. 25, no. 6,pp. 677-685.

[10] Armeli, S., Eisenberger, R., Fasolo, P. \& Lynch, P. (1998) 'Perceived organizational support and police performance: the moderating influence of socioemotional needs', Journal of Applied Psychology, vol. 83, no. 2, p. 288.

[11] Atkinson, P. (1990) Creating culture change: The key to successful Total Quality Management, IFS Publishers, London.

[12] Azzara, C.V. (2010) Questionnaire Design for Business Research: Beyond Linear Thinking--an Interactive Approach, Tate Publishing.

[13] Bauer, J.E., Duffy, G.L. \& Westcott, R. (2006) The quality improvement handbook, ASQ Quality Press Milwaukee, WI.

[14] Bennett, W.W., Hess, K.M. \& Orthmann, C.M. (2004) Management and supervision in law enforcement, Wadsworth/Thomson Learning Belmont, CA.

[15] Berman, E.M. \& West, J.P. (1995). 'Municipal commitment to total quality management: a survey of recent progress', Public Administration Review, pp. 57-66.

[16] Bou-Llusar, J.C., Escrig-Tena, A.B., Roca-Puig, V. \& BeltránMartín, I. (2009) 'An empirical assessment of the EFQM Excellence Model: Evaluation as a TQM framework relative to the MBNQA Model', Journal of Operations Management, vol. 27, no. 1, pp. 1-22.

[17] Brain, T. (2010) A history of policing in England and Wales from 1974: a turbulent journey, Oxford University Press.

[18] Browne, M.N. \& Keeley, S.M. (1981) Asking the right questions, Prentice-Hall Englewood Cliffs, New Jersey.

[19] Bryman, A. \& Bell, E. (2007) Business research methods, Oxford university press.

[20] Burns, R.P. \& Burns, R. (2008) Business research methods and statistics using SPSS, Sage.

[21] Business Performance Improvement Resource (2011) History of Quality.

[22] Buttle, F. (1996) 'SERVQUAL: review, critique, research agenda', European Journal of marketing, vol. 30, no. 1, pp. 8-32.

[23] Calabrese, R.L. (2009) The dissertation desk reference: the doctoral student's manual to writing the dissertation, R\&L Education.

[24] Caless, B. (2007) 'Numties in Yellow Jackets': The Nature of Hostility Towards the Police Community Support Officer in Neighbourhood Policing Teams', Policing, vol. 1, no. 2, pp. 187195.

[25] Carr, C.L. (2002) 'A Psychometric Evaluation of the Expectations, Perceptions, and Difference-Scores Generated by the IS-Adapted SERVQUAL Instrument', Decision Sciences, vol. 33, no. 2, pp. 281-296.

[26] Central Intelligence Agency (2012) Qatar: CIA World Factbook, 23 January 2013 edn.

[27] Charintimath, P.M. (2003) Total Quality Management, Dorling Kindersley, Delhi, India. 
[28] Cheng, J.-L. (2008) 'Implementing Six Sigma via TQM improvement: an empirical study in Taiwan', The TQM Journal, vol. 20, no. 3, pp. 182-195.

[29] Choi, T.Y. \& Eboch, K. (1998) 'The TQM paradox: relations among TQM practices, plant performance, and customer satisfaction', Journal of Operations Management, vol. 17, no. 1, pp. 59-75.

[30] Chung, Y.-C., Tien, S.-W., Hsieh, C.-H. \& Tsai, C.-H. (2008) 'A study of the business value of total quality management', Total Quality Management, vol. 19, no. 4, pp. 367-379.

[31] Coleman, R. (2004) Reclaiming the streets: Surveillance, social control and the city, Taylor and Francis, New York.

[32] Colton, D. \& Covert, R.W. (2007) Designing and constructing instruments for social research and evaluation, John Wiley \& Sons.

[33] Committee, D.P. (1992) The Deming prize guide, Tokyo.

[34] Cook, C. \& Thompson, B. (2000) 'Reliability and validity of SERVQUAL scores used to evaluate perceptions of library service quality', The Journal of Academic Librarianship, vol. 26, no. 4, pp. 248-258.

[35] Cordesman, A.H. \& Al-Rodhan, K.R. (2006) Gulf military forces in an era of asymmetric wars, Greenwood Publishing Group.

[36] Corredor, P. \& Goñi, S. (2011) 'TQM and performance: Is the relationship so obvious?', Journal of Business Research, vol. 64, no. 8, pp. 830-838.

[37] Cox, J.W. (2009) Critical Management Studies at Work: Negotiating Tensions between Theory and Practice: E-BOOK, Edward Elgar Publishing.

[38] Creswell, J.W. (2009) Research design: Qualitative, quantitative, and mixed methods approaches, Sage.

[39] Crosby, P.B. (1985) Quality without tears: The art of hassle-free management, New American Library.

[40] Crotty, M. (1998). The foundations of social research: Meaning and perspective in the research process, Sage.

[41] Crowther, D. \& Lancaster, G. (2009) Research methods: a concise introduction to research in management and business consultancy, Routledge.

[42] Curwin, J. \& Slater, R. (2008) Quantitative methods for business decisions, CengageBrain. com.

[43] D.H., B., C., B.M. \& M., B.S. (2003) Total Quality Management, 3 edn, Upper Saddleback River, NJ : Pearson Educational.

[44] Dakic, S. (2010) 'The importance of TQM concept as a factor of competitive advantage of companies', Perspectives of Innovations, Economics and Business, PIEB, no. 3 (6), pp. 18-20.

[45] De Feo, J.A. (2010) Juran's quality handbook: The complete guide to performance excellence, McGraw Hill.

[46] De Feo, J.A. \& Barnard, W. (2003) Juran Institute's six sigma: breakthrough and beyond: quality performance breakthrough methods, McGraw-Hill Professional.

[47] Dean, J.W. \& Bowen, D.E. (1994) 'Management theory and total quality: improving research and practice through theory development', Academy of management review, vol. 19, no. 3, pp. 392-418.

[48] Deming's Cycle, vol., [Online]. Available from: http://totalqualitymanagement.wordpress.com/tag/deming-cycle/ (Accessed: 2013).

[49] Demming, W.E. (1986) 'Out of the Crisis', Massachusetts Institute of Technology, Cambridge, MA.

[50] Denzin, N.K. \& Lincoln, Y.S. (2011) The SAGE handbook of qualitative research, Sage.

[51] Donnelly, M., Kerr, N.J., Rimmer, R. \& Shiu, E.M. (2006) 'Assessing the quality of police services using SERVQUAL', Policing: an international journal of police strategies \& management, vol. 29, no. 1, pp. 92-105.

[52] Douglas, T.J. \& Judge, W.Q. (2001) 'Total quality management implementation and competitive advantage: the role of structural control and exploration', Academy of Management Journal, vol. 44, no. 1, pp. 158-169.

[53] Easterby-Smith, M., Thorpe, R. \& Jackson, P. (2012) Management research, Sage Publications.

[54] Echagüe, A. (2007) The European Union and the Gulf Cooperation Council, FRIDE Working Paper, Fundación par alas Relaciones Internacionales y el Diálogos Exterior, Madrid,

[55] Ehrlich, C. (2006) 'The EFQM-model and work motivation', Total Quality Management \& Business Excellence, vol. 17, no. 2, pp. 131-140.
[56] Ehteshami, A. \& Wright, S. (2007) 'Political change in the Arab oil monarchies: from liberalization to enfranchisement', International Affairs, vol. 83, no. 5, pp. 913-932.

[57] Eskildsen, J.K. \& Dahlgaard, J.J. (2000) 'A causal model for employee satisfaction', Total Quality Management, vol. 11, no. 8, pp. 1081-1094.

[58] Feigenbaum, A.V. (1951) Quality control: Principles, practice and administration: An industrial management tool for improving product quality and design and for reducing operating costs and losses, McGraw-Hill.

[59] Feigenbaum, A.V. (2005) Total quality control: achieving productivity, market penetration and advantage in the global economy, McGraw-Hill Higher Education.

[60] Fernandez, S. \& Rainey, H.G. (2006) 'Managing successful organizational change in the public sector', Public Administration Review, vol. 66, no. 2, pp. 168-176.

[61] Fisher, N. \& Nair, V. (2009) 'Quality management and quality practice: Perspectives on their history and their future', Applied Stochastic Models in Business and Industry, vol. 25, no. 1, pp. 128.

[62] Flexstudy (2011) Quality and Service in Manufacturing.

[63] Fotopoulos, C.V., Psomas, E.L. \& Vouzas, F.K. (2010) 'Investigating total quality management practice's interrelationships in ISO 9001: 2000 certified organisations', Total Quality Management, vol. 21, no. 5, pp. 503-515.

[64] Fowler, F.J. (2009) Survey research methods, vol. 1, Sage.

[65] Frenz, M. (2009) Research Methods in Management, SAGE, Thousand Oaks, CA.

[66] Fromherz, A.J. (2012) Qatar: a modern history, Georgetown University Press.

[67] Gale, B. \& Wood, R.C. (1994). Managing customer value: Creating quality and service that customers can see, Simon and Schuster.

[68] Geoff, T. (2001) Six Sigma: SPC and TQM in manufacturing and services, Gower Publishing, Ltd.

[69] Ghobadian, A. \& Gallear, D. (2001) 'TQM implementation: an empirical examination and proposed generic model', Omega, vol. 29, no. 4, pp. 343-359.

[70] Ghylin, K., Green, B., Drury, C., Chen, J., Schultz, J., Uggirala, A., Abraham, J. \& Lawson, T. (2008). 'Clarifying the dimensions of four concepts of quality', Theoretical Issues in Ergonomics Science, vol. 9, no. 1, pp. 73-94.

[71] Gill, J. \& Johnson, P. (2002). Research methods for managers, Sage.

[72] Gillham, B. (2005). 'Research interviewing: The range of techniques'.

[73] Godfey, A. (1999). Total Quality Management, McGraw-Hill, New York, NY.

[74] Greasley, A. (2004). 'Process improvement within a HR division at a UK police force', International Journal of Operations \& Production Management, vol. 24, no. 3, pp. 230-240.

[75] Gummesson, E. (2000). Qualitative methods in management research, Sage.

[76] Hakes, C. (2007). The EFQM Excellence Model for Assessing Organizational Performance: A Management Guide, Van Haren Publishing.

[77] Hanna, M.D. \& Newman, W.R. (1995). 'Operations and environment: an expanded focus for TQM', International Journal of Quality \& Reliability Management, vol. 12, no. 5, pp. 38-53.

[78] Harry, M., Mann, P.S., De Hodgins, O.C., Hulbert, R.L. \& Lacke, C.J. (2010). The practitioner's guide to statistics and lean Six Sigma for process improvements, John Wiley \& Sons.

[79] Harry, M.J. \& Schroeder, R. (2006). Six Sigma: The breakthrough management strategy revolutionizing the world's top corporations, Random House Digital, Inc.

[80] Henry, C.M. \& Springborg, R. (2010). Globalization and the Politics of Development in the Middle East, vol. 1, Cambridge University Press.

[81] Hesse-Biber, S.N. (2010). Mixed methods research: Merging theory with practice, Guilford Press.

[82] Hill, N. \& Alexander, J. (2000). Handbook of Customer Satisfaction and Loyality Measurement, Gower Publishing, Ltd.

[83] Ho, D., Duffy, V. \& Shih, H. (2001). 'Total quality management: an empirical test for mediation effect', International Journal of Production Research, vol. 39, no. 3, pp. 529-548.

[84] Hoang, D.T., Igel, B. \& Laosirihongthong, T. (2010). 'Total quality management (TQM) strategy and organisational 
characteristics: Evidence from a recent WTO member', Total quality management, vol. 21, no. 9, pp. 931-951.

[85] Hofstede, G. (1980). 'Motivation, leadership, and organization: do American theories apply abroad?', Organizational dynamics, vol. 9, no. 1,pp. 42-63.

[86] Hofstede, G. \& Bond, M.H. (1988). 'The Confucius connection: From cultural roots to economic growth', Organizational dynamics, vol. 16 , no. 4, pp. 5-21.

[87] Hofstede, G., Hofstede, G.J. \& Minkov, M. (1991) Cultures and organizations: Software of the mind, vol. 2, McGraw-Hill London.

[88] Hofstede, G.H. (2001) Culture's consequences: Comparing values, behaviors, institutions and organizations across nations, Sage.

[89] Hoftstede, G. (1980) Culture's consequences: International differences in work-related values, London: Sage.

[90] Holjevac, I.A. (2008) 'Business ethics in tourism-as a dimension of TQM', Total Quality Management \& Business Excellence, vol. 19, no. 10,pp. 1029-1041.

[91] Hough, M. (2004) 'Updating our TQM thinking for a knowledge and service economy', Total Quality Management \& Business Excellence, vol. 15, no. 5-6,pp. 753-791.

[92] Hsu, S.-H. \& Shen, H.-P. (2005) 'Knowledge management and its relationship with TQM', Total Quality Management and Business Excellence, vol. 16, no. 3,pp. 351-361.

[93] Hughes, P.J. (2010) Increasing Organizational Leadership Through the Police Promotional Process, vol., [Online]. Available from: www.fbi.gov.stats (Accessed.

[94] Hung, H.-M. (2007) 'Influence of the environment on innovation performance of TQM', Total Quality Management \& Business Excellence, vol. 18, no. 7,pp. 715-730.

[95] Hung, R.Y.-Y. (2006) 'Business process management as competitive advantage: a review and empirical study', Total Quality Management \& Business Excellence, vol. 17, no. 1,pp. 2140.

[96] Hunter, J.E. \& Schmidt, F.L. (2004) Methods of meta-analysis: Correcting error and bias in research findings, Sage.

[97] Hyde, A.C. (1993) 'Implications of Total Quality Management for the Public Sector', Public Productivity and Management Review, vol. 16, pp. 23-23.

[98] Inkeles, A. \& Levinson, D.J. (1969) 'National character: The study of modal personality and sociocultural systems', The handbook of social psychology, vol. 4, pp. 418-506.

[99] Ioimo, R., Tears, R.S., Meadows, L.A., Becton, J.B. \& Charles, M.T. (2007) 'The police view of bias-based policing', Police Quarterly, vol. 10, no. 3,pp. 270-287.

[100] Ishikawa, K. (1985) 'What is total quality control the Japanese way'.

[101] Jackson, S.L. (2010) Research methods: a modular approach, Cengage Learning.

[102] Janakiraman, B. \& Gopal, R. (2003) Total quality management: Text and cases, 3 edn, PHI Learning Pvt. Ltd.

[103] Janakiraman, B. \& Gopal, R. (2006) Total quality management: Text and cases, PHI Learning Pvt. Ltd.

[104] Jayaram, J., Ahire, S.L. \& Dreyfus, P. (2010) 'Contingency relationships of firm size, TQM duration, unionization, and industry context on TQM implementation-A focus on total effects', Journal of operations Management, vol. 28, no. 4,pp. 345-356.

[105] Jermier, J.M. \& Berkes, L.J. (1979) 'Leader behavior in a police command bureaucracy: A closer look at the quasi-military model', Administrative Science Quarterly, pp. 1-23.

[106] Joiner, T.A. (2007) 'Total quality management and performance: The role of organization support and co-worker support', International Journal of Quality \& Reliability Management, vol. 24, no. 6,pp. 617-627.

[107] JONES, M. (2008) 'A complexity science view of modern police administration', Public Administration Quarterly, pp. 433-457.

[108] Jun, M., Cai, S. \& Peterson, R. (2004) 'Obstacles to TQM implementation in Mexico's Maquiladora industry', Total Quality Management \& Business Excellence, vol. 15, no. 1,pp. 59-72.

[109] Juran, J.M. (1995) A history of managing for quality: The evolution, trends, and future directions of managing for quality, ASQC Quality Press Milwaukee, WI.

[110] Kakuro, A. (2004) 'Development of 'science TQM', a new principle of quality management: effectiveness of strategic stratified task team at Toyota', International Journal of Production Research, vol. 42, no. 17,pp. 3691-3706.
[111] Kamrava, M. (2009) 'Royal factionalism and political liberalization in Qatar', The Middle East Journal, vol. 63, no. 3,pp. 401-420.

[112] Kanji, G. (2002) Measuring business excellence, routledge advances in management and business studies, Routledge London.

[113] Kannan, V.R. \& Tan, K.C. (2005) 'Just in time, total quality management, and supply chain management: understanding their linkages and impact on business performance', Omega, vol. 33, no. 2,pp. 153-162.

[114] Karami, A., Rowley, J. \& Analoui, F. (2006) 'Research and knowledge building in management studies: an analysis of methodological preferences', International Journal, vol. 23, no. 1,pp. 43-52.

[115] Kaynak, H. (2003) 'The relationship between total quality management practices and their effects on firm performance', Journal of operations management, vol. 21, no. 4,pp. 405-435.

[116] Kaynak, H. \& Hartley, J.L. (2008) 'A replication and extension of quality management into the supply chain', Journal of Operations Management, vol. 26, no. 4,pp. 468-489.

[117] Keel, T.G. (2008) 'Homicide Investigations: Identifying Best Practices', FBI Law Enforcement Bulletin, pp. 1-10.

[118] Kehoe, D.F. (1996) The Fundamentals of quality management, Chapman \& Hall.

[119] Khamalah, J.N. \& Lingaraj, B.P. (2007) 'TQM in the service sector: a survey of small businesses', Total quality management, vol. 18, no. 9,pp. 973-982.

[120] Kluse, C. (2009) 'Case Study: TQM and the Government-The Importance of Leadership and Personal Transformation', Journal for Quality and Participation, vol. 32, no. 3.

[121] Knowledge@Wharton (2005) TQM, ISO 9000, Six Sigma: Do Process Management Programs Discourage Innovation?

[122] Koehler, J.W. \& Pankowski, J.M. (1996) Quality government: Designing, developing, and implementing TQM, CRC Press.

[123] Kull, T.J. \& Wacker, J.G. (2010) 'Quality management effectiveness in Asia: The influence of culture', Journal of Operations Management, vol. 28, no. 3,pp. 223-239.

[124] Ladhari, R. (2009) 'A review of twenty years of SERVQUAL research', International Journal of Quality and Service Sciences, vol. 1, no. 2,pp. 172-198.

[125] Lambert, J. (2011) 'Political Reform in Qatar: Participation, Legitimacy and Security', Middle East Policy, vol. 18, no. 1,pp. 89-101.

[126] Langford, D. (2006) 'How the Air Force Embraced "Partial Quality”(and Avoiding Similar Mistakes in New Endeavors)', Air \& Space Power Journal.

[127] Levy, Y. (2010) 'The Essence of the "Market Army”', Public Administration Review, vol. 70, no. 3,pp. 378-389.

[128] Longest, B.B., Rakich, J.S. \& Darr, K. (2000) Managing Health Services Systems and Organisations, Health Professions Press, Baltimore, MD.

[129] López-Mielgo, N., Montes-Peón, J.M. \& Vázquez-Ordás, C.J. (2009) 'Are quality and innovation management conflicting activities?', Technovation, vol. 29, no. 8,pp. 537-545.

[130] Lynch, R.G. \& Lynch, S.R. (2010) The police manager, Access Online via Elsevier.

[131] Maklan, S. \& Klaus, P. (2011) 'Customer experience: are we measuring the right things?', International Journal of Market Research, vol. 53, no. 6,pp. 771-792.

[132] Martínez-Costa, M., Choi, T.Y., Martínez, J.A. \& MartínezLorente, A.R. (2009) 'ISO 9000/1994, ISO 9001/2000 and TQM: the performance debate revisited', Journal of Operations Management, vol. 27, no. 6,pp. 495-511.

[133] Mawby, R.C. \& Worthington, S. (2002) 'Marketing the Policefrom a Force to a Service', Journal of Marketing Management, vol. 18, no. 9-10,pp. 857-876.

[134] May, T. (2002) Qualitative research in action, Sage.

[135] McAdam, R., Leonard, D., Henderson, J. \& Hazlett, S.-A. (2008) 'A grounded theory research approach to building and testing TQM theory in operations management', Omega, vol. 36, no. 5,pp. 825-837.

[136] McLeod, C. (2003) 'Toward a restorative organization: transforming police bureaucracies', Police Practice and Research, vol. 4, no. 4,pp. 361-377.

[137] Mehra, S. \& Ranganathan, S. (2008) 'Implementing total quality management with a focus on enhancing customer satisfaction', International Journal of Quality \& Reliability Management, vol. 25, no. 9,pp. 913-927. 
[138] Merseyside Police Authority (2012) Merseyside Police, 14 April 2012 edn.

[139] Ministry of Business and Finance (2011) Qatar's Investment Environment.

[140] Mohr-Jackson, I. (1998) 'Conceptualizing total quality orientation', European Journal of Marketing, vol. 32, no. 1/2,pp. 13-22.

[141] Moura E Sá, P. \& Abrunhosa, A. (2007) 'The role of TQM practices in technological innovation: the Portuguese footwear industry case', Total Quality Management \& Business Excellence, vol. 18, no. 1-2,pp. 57-66.

[142] Moutinho, L. \& Hutcheson, G.D. (2011) The SAGE dictionary of quantitative management research, Sage.

[143] Office of National Statistics (2011) Population estimates for UK, England and Wales, Scotland and Northern Ireland, 14 April 2012 edn.

[144] Oxford Business Group (2011) The Report: Qatar 2011, Oxford Business Group, London.

[145] Pallant, J. (2004) SPSS survival manual: version 12, Open University Press.

[146] Pallant, J. \& Manual, S.S. (2001) 'Open University Press', Buckingham and Philadelphia.

[147] Parasuraman, A., Zeithaml, V.A. \& Berry, L. (1990) 'Delivering quality service', Nova Yorque: The Free Press.

[148] Parasuraman, A., Zeithaml, V.A. \& Berry, L. (2004) 'SERVQUAL: a multiple-item scale for measuring consumer perceptions of service quality', Retailing: Crit Concepts Bk2, vol. 64, no. 1,p. 140.

[149] Perdomo-Ortiz, J., González-Benito, J. \& Galende, J. (2006) 'Total quality management as a forerunner of business innovation capability', Technovation, vol. 26, no. 10,pp. 1170-1185.

[150] Peters, T. \& Rodabaugh, K. (1988) 'Thriving on chaos: Handbook for a management revolution', The Journal of Continuing Higher Education, vol. 36, no. 2,pp. 27-28.

[151] Peters, T.J. \& Waterman, R.H. (2004) In search of excellence: Lessons from America's best-run companies, HarperCollins.

[152] Peterson, J. (2006) 'Qatar and the world: Branding for a microstate', The Middle East Journal, pp. 732-748.

[153] Pfeffer, J. \& Sutton, R.I. (2006) 'Evidence-based management', Harvard business review, vol. 84, no. 1,p. 62.

[154] Plano Clark, V.L. \& Creswell, J.W. (2008) 'The mixed methods reader', Los Angeles, ao.

[155] Powell, T.C. (1995) 'Total quality management as competitive advantage: a review and empirical study', Strategic management journal, vol. 16, no. 1,pp. 15-37.

[156] Prajogo, D. Issues in Six Sigma Implementation-Reflection from TQM, Six Sigma 2007 Conference.

[157] Prajogo, D.I. (2006) 'Progress of quality management practices in Australian manufacturing firms', The TQM Magazine, vol. 18, no. 5,pp. 501-513.

[158] Prajogo, D.I. \& Brown, A. (2004) 'The relationship between TQM practices and quality performance and the role of formal TQM programs: An Australian empirical study'.

[159] Prajogo, D.I. \& Cooper, B.K. (2010) 'The effect of people-related TQM practices on job satisfaction: a hierarchical model', Production Planning and Control, vol. 21, no. 1,pp. 26-35.

[160] Prajogo, D.I. \& Sohal, A.S. (2006) 'The relationship between organization strategy, total quality management (TQM), and organization performance-the mediating role of TQM', European Journal of Operational Research, vol. 168, no. 1,pp. 35-50.

[161] Pritchard, R.D., Culbertson, S.S., Malm, K. \& Agrell, A. (2009) 'Improving performance in a Swedish police traffic unit: Results of an intervention', Journal of Criminal Justice, vol. 37, no. 1,pp. 8597.

[162] Punch, K.F. (2005) Introduction to social research: Quantitative and qualitative approaches, Sage.

[163] Rawlins, R.A. (2008) Total Quality Management (TQM), AuthorHouse.

[164] Reed, R., Lemak, D.J. \& Mero, N.P. (2000) 'Total quality management and sustainable competitive advantage', Journal of quality management, vol. 5, no. 1,pp. 5-26.

[165] Remenyi, D. (1998) Doing research in business and management: an introduction to process and method, Sage.

[166] Ridenour, C.S. \& Newman, I. (2008) Mixed methods research: Exploring the interactive continuum, SIU Press.

[167] Riley, M. (2000) Researching and writing dissertations in business and management, CengageBrain. com.

[168] Riley, W. \& Brewer, R. (2009) 'Review and analysis of quality improvement techniques in police departments: application for public health', Journal of Public Health Management and Practice, vol. 15, no. 2,pp. 139-149.

[169] Ritsert, R. \& Pekar, M. (2009) 'New Public Management Reforms in German Police Services', German Policy Studies, vol. 2, p. 30.

[170] Robson, C. (2002) Real world research: A resource for social scientists and practitioner-researchers, vol. 2, Blackwell Oxford.

[171] Roulston, K. (2010) Reflective interviewing: A guide to theory and practice, Sage.

[172] Ruffa, S.A. (2008) Going lean: how the best companies apply lean manufacturing principles to shatter uncertainty, drive innovation, and maximize profits, Amacom.

[173] Ruiz-Carrillo, J.I.C. \& Fernández-Ortiz, R. (2005) 'Theoretical foundation of the EFQM model: the resource-based view', Total Quality Management \& Business Excellence, vol. 16, no. 1,pp. 3155.

[174] Russell, S. (2000) 'ISO 9000: 2000 and the EFQM excellence model: competition or co-operation?', Total Quality Management, vol. 11, no. 4-6,pp. 657-665.

[175] Saunders, M.N., Saunders, M., Lewis, P. \& Thornhill, A. (2011) Research Methods For Business Students, 5/e, Pearson Education India.

[176] Saylor, J.H. (1992) TQM field manual, McGraw-Hill.

[177] Scottish Housing Register (2011) Section 4 Techniques and Tools, vol., [Online]. Available from: http://www.communitiesscotland.gov.uk/stellent/groups/public/do cuments/webpages/shr_howt (Accessed: 10 January 2012).

[178] Selen, W.J. \& Schepers, J. (2001) 'Design of quality service systems in the public sector: use of quality function deployment in police services', Total Quality Management, vol. 12, no. 5,pp. 677 687.

[179] Seth, N., Deshmukh, S. \& Vrat, P. (2005) 'Service quality models: a review', International Journal of Quality \& Reliability Management, vol. 22, no. 9,pp. 913-949.

[180] Sewell-Staples, W.J., Dalrymple, J.F. \& Phipps, K. (2003) 'Auditing excellence in call centres: access is a corporate responsibility', Managerial Auditing Journal, vol. 18, no. 1,pp. 6875.

[181] Shapiro, D.L., Kirkman, B.L. \& Courtney, H.G. (2007) 'Perceived causes and solutions of the translation problem in management research', Academy of Management Journal, vol. 50, no. 2,pp. 249-266.

[182] Siddle, J. (2011) Merseyside Police Officers Used Classified Records Illegally 208 Times in Three Years, vol., [Online]. Available from: http://www.liverpoolecho.co.uk/liverpoolnews/local-news/2011/06/27/merseyside-police-officers-usedclassified-records-illegally-208-times-in-three-years-10025228946604/ (Accessed: 10 January 2012).

[183] Sila, I. (2007) 'Examining the effects of contextual factors on TQM and performance through the lens of organizational theories: an empirical study', Journal of Operations management, vol. 25, no. 1,pp. 83-109.

[184] Sila, I. \& Ebrahimpour, M. (2003) 'Examination and comparison of the critical factors of total quality management (TQM) across countries', International Journal of Production Research, vol. 41, no. 2,pp. 235-268.

[185] Silvers, J.R. Cause and effect diagram, vol., [Online]. Available from:

http://www.juliasilvers.com/embok/Guide/RSK/RiskAssessment Mgmt/causeeffect_analysis.htm (Accessed: 2013).

[186] Sliwa, M. \& Wilcox, M. (2008) 'Philosophical thought and the origins of quality management: uncovering conceptual underpinnings of WA Shewhart's ideas on quality', Culture and Organization, vol. 14, no. 1,pp. 97-106.

[187] Soltani, E. \& Wilkinson, A. (2010) 'Stuck in the middle with you: The effects of incongruency of senior and middle managers' orientations on TQM programmes', International Journal of Operations \& Production Management, vol. 30, no. 4,pp. 365-397.

[188] Stasz, C., Eide, E.R. \& Martorell, P. (2008) Post-secondary education in Qatar: Employer demand, student choice, and options for policy, Rand Corporation.

[189] Steed, C., Maslow, D. \& Mazaletskaya, A. (2005) 'The EFQM Excellence Model for Deploying Quality Management: A British-Russian Journey', Higher education in Europe, vol. 30, no. 3-4,pp. 307-319.

[190] Steinheider, B. \& Wuestewald, T. (2008) 'From the bottom-up: sharing leadership in a police agency', Police Practice and Research: An International Journal, vol. 9, no. 2,pp. 145-163. 
[191] Stodnick, M. \& Rogers, P. (2008) 'Using SERVQUAL to measure the quality of the classroom experience', Decision Sciences Journal of Innovative Education, vol. 6, no. 1,pp. 115-133.

[192] Swiss, J.E. (1992) 'Adapting total quality management (TQM) to government', Public Administration Review, pp. 356-362.

[193] Szwarc, P. (2005) Researching customer satisfaction \& loyalty [electronic resource]: how to find out what people really think, Kogan Page Publishers.

[194] Tarí, J.J. (2006) 'Improving service quality in a Spanish police service', Total Quality Management \& Business Excellence, vol. 17, no. 3,pp. 409-424.

[195] Tari, J.J., Molina, J.F. \& Castejon, J.L. (2007) 'The relationship between quality management practices and their effects on quality outcomes', European Journal of Operational Research, vol. 183, no. 2,pp. 483-501.

[196] Taylor, F. (2011) What is the Deming Prize The W. Edwards Deming Institute.

[197] Terlaak, A. \& King, A.A. (2006) 'The effect of certification with the ISO 9000 Quality Management Standard: A signaling approach', Journal of Economic Behavior \& Organization, vol. 60, no. 4,pp. 579-602.

[198] The Crown Prosecution Service (2011) Merseyside Police Officer Charged with Misconduct in Public Office, vol., [Online]. Available from: http://blog.cps.gov.uk/2011/02/cps-updatethursday-24-february-2011.html (Accessed: 10 Janury 2012).

[199] The Liverpool Echo (2010) Merseyside Police could loose up to 800 officers in Budget Slash, vol., [Online]. Available from: http://www.liverpoolecho.co.uk/liverpool-news/localnews/2010/07/09/merseyside-policecould- (Accessed: 14 April 2012).

[200] Thomas, R.M. (2003) Blending qualitative and quantitative research methods in theses and dissertations, Corwin-volume discounts.
[201] Toch, H. (2008) 'Police officers as change agents in police reform', Policing \& Society, vol. 18, no. 1,pp. 60-71.

[202] Trochim, W.M. \& Donnelly, J.P. (2008) Research methods knowledge base, Atomic Dog/Cengage Learning Mason, OH.

[203] United States Army (2002) Army Regulation 5.1: Army Total Quality Management, Department of Defence, Washington D.C.

[204] Vogt, W.P., Gardner, D.C. \& Haeffele, L.M. (2012) When to use what research design, Guilford Press.

[205] Watson, G.E. \& Gallagher, J.K. (2005) Managing for Results, CIPD Publishing.

[206] Wayhan, V.B., Khumawala, B.M. \& Balderson, E.L. (2010) 'An empirical test of Deming's chain reaction model', Total Quality Management, vol. 21, no. 7,pp. 761-777.

[207] Wellman, Richard, Pittsburg, Thomas, B. \& Susan, S. (2003) 'Six Sigma and the U.S. Army: A Potential for Excellence', Proceedings of the Academy of Strategic Management, vol. 2, no. 2,pp. 15-21.

[208] Wolcott, H.F. (1990) Writing up qualitative research (Vol. 20), Newbury Park, CA: Sage.

[209] Wolek, F.W. (1999) 'Ye olde total quality management', Total quality management, vol. 10, no. 7,pp. 1077-1084.

[210] Wright, R., Powell, M.B. \& Ridge, D. (2007) 'What criteria do police officers use to measure the success of an interview with a child?', Psychology, Crime \& Law, vol. 13, no. 4,pp. 395-404.

[211] Zbaracki, M.J. (1998) 'The rhetoric and reality of total quality management', Administrative Science Quarterly, pp. 602-636.

[212] Zeithaml, V.A., Parasuraman, A. \& Berry, L.L. (1990) 'Delivering quality service', New York.

[213] Zu, X., Fredendall, L.D. \& Douglas, T.J. (2008) 'The evolving theory of quality management: the role of Six Sigma', Journal of operations Management, vol. 26, no. 5,pp. 630-650. 